Historic, Archive Document

Do not assume content reflects current scientific knowledge, policies, or practices. 



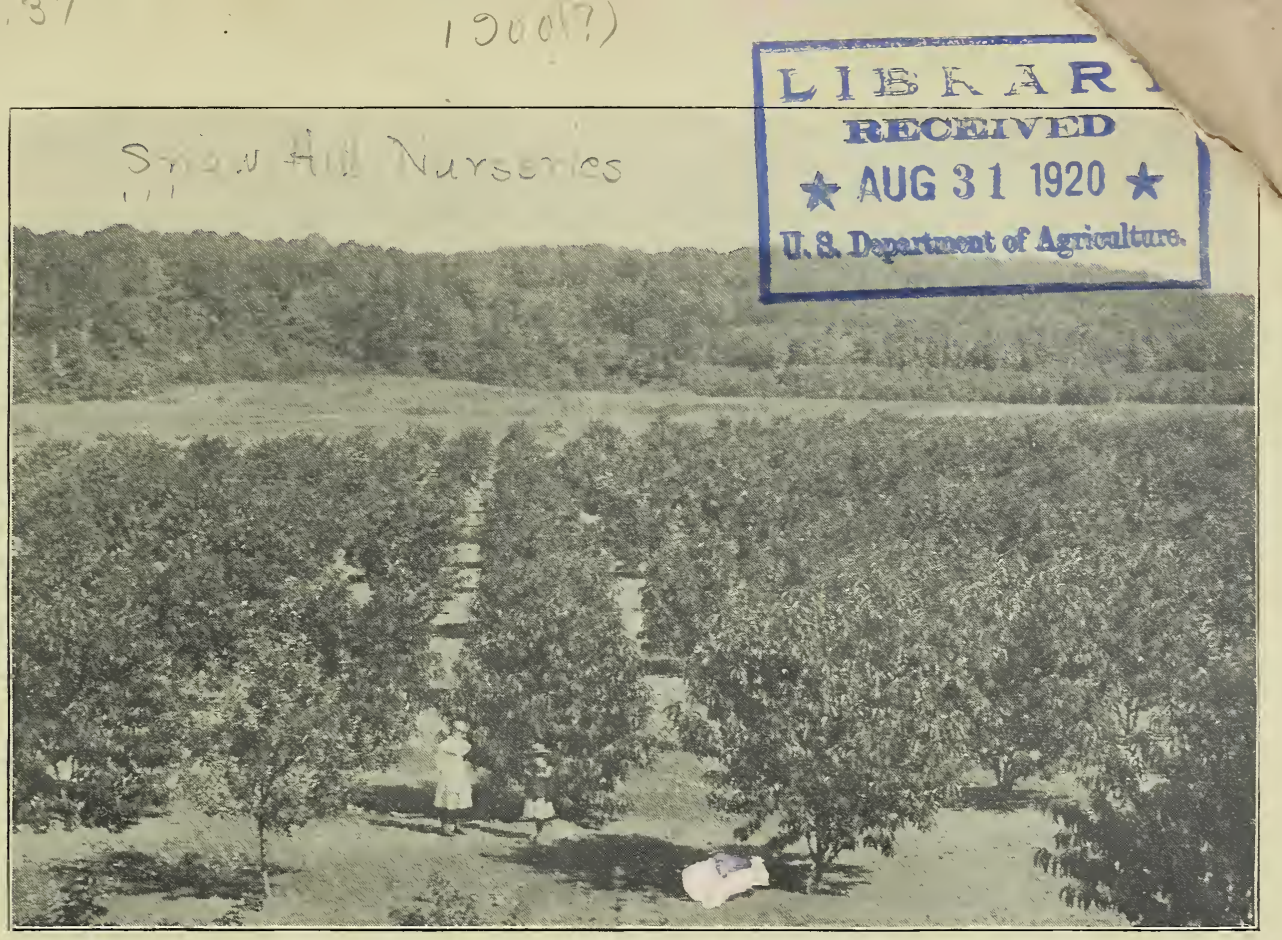

C. W. WARD'S PEACH ORCHARD, QUEENS, L. I., NEW YORK

\section{A Peach Orchard from Peters' Trees}

Planted April, 1897, June-budded Trees

\section{WITH TWO YEARS OF GROWTH}

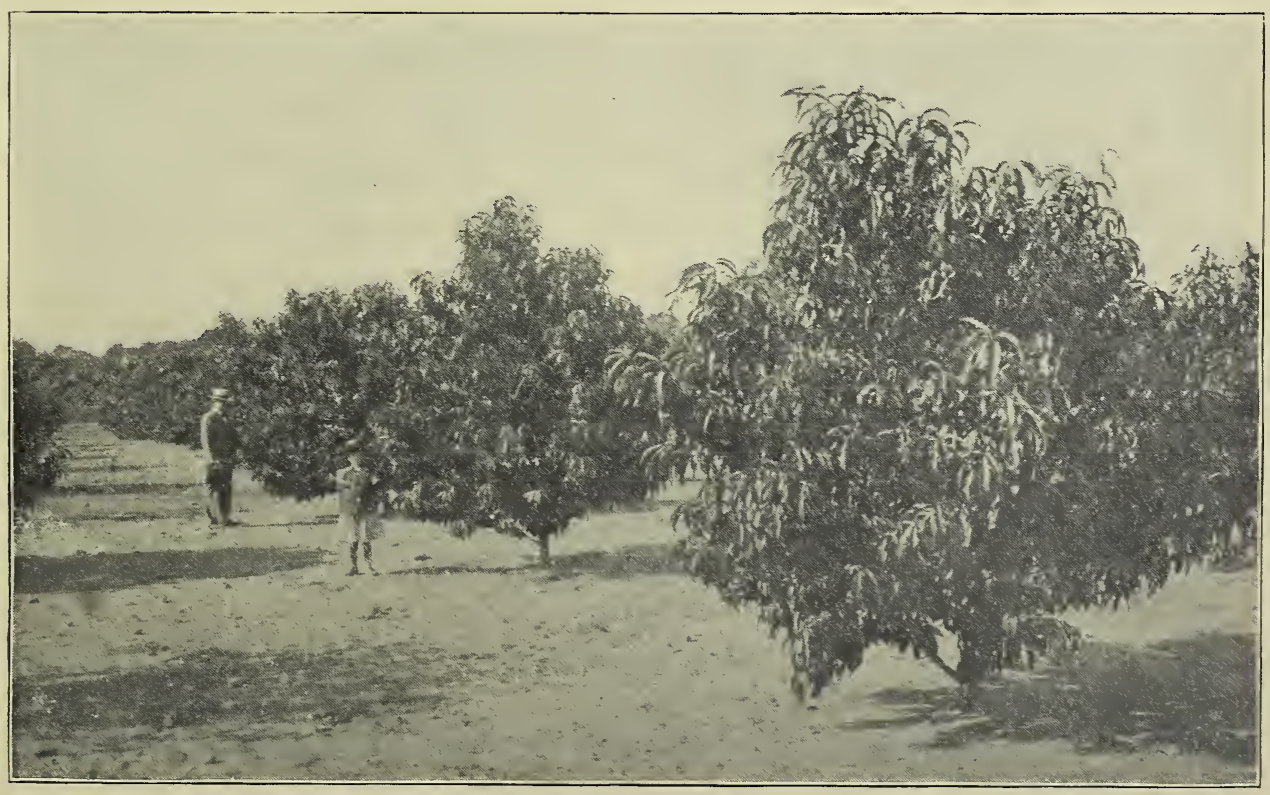




\section{with Our Well-grown Trees}

The following letter, and the pictures on the other side of this sheet, explain themselves:

\section{The Cottage Gardeng}

C. W. WARD, Manager

Importers, Growers and Originators

QueEns, N. Y., Sept. I8, 1899.

Messrs. W. M. Peters' Sons, Wesley, Md.

Dear Sirs - At last I am able to send you the photographs in good shape.

These trees were planted in April, 1897, June buds, about 16 to 20 inches high. They bore a few peaches to each tree, not more than ten being allowed to mature on any tree, and most trees only three or four, to prove variety.

Soil is gravelly loam, formed by glacial moraine, with quite some stones, and clay subsoil four or five feet down, overlaid with gravel and underlaid with sharp, porous sand. No trees were killed last winter.

Cultivation same as for orange orchards in Florida; very shallow, with frequent harrowings to keep down weeds. No manure or fertilizer, save about 300 pounds unleached ashes per acre, sown in April, 1899. No yellow's or scale of any kind. Sprayed with whale-oil soap solution, I pound to 2 gallons of water, each spring, before growth commences.

Our photograph shows the ridge of timber to the northwest which shelters us from the fierce westerly, northwesterly, and northerly gales. Trees are set 20 feet apart, quincunx order, with apple trees 40 feet apart, to come on and occupy the ground after the peach trees quit.

The open lots just under the ridge are now being plowed for planting the $\mathrm{r}$, ooo trees ordered from you a short time since.

All these trees were purchased from your firm, save the apple trees. Yours sincerely,

C. W. WARD

Thus this orchard, properly cared for, and starting properly with our honestlygrown, healthy trees, has made a most remarkable growth, and has endured without damage the worst winter in a generation.

Doesn't it pay to plant the best peach trees?

W. M. PETERS' SONS, Wesley, Maryland 


\section{W. M. Peters' Sons}

.. Snow Hill Nurserieś..

IRONSHIRE, MARYLAND

Wesley, MaryLand

(Address all correspondence to WESLEY, MD.)

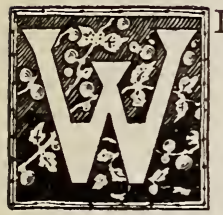

ITH a thoroughly revised Catalogue of a stock never better, we come before our friends. We use this expression advisedly, for our desire is to so deal with customers as to make them friends, and we are proud of the pleasant letters we get from those who have purchased our trees during many years past.

Our nursery experience extends over a generation, and our operations in growing trees and fruits for many years have ripened our judgment and given us the discriminating experience only obtained with time. It is, therefore, with the confidence and knowledge born of experience and practice that we present at this time our selections of

\section{FRUIT-BEARING FRUIT TREES.}

Surprise may be expressed at the apparent implication that some fruit trees are not fruit-bearing; yet such is the fact, and the lamentable condition in many places of orchards carefully grown, yet unsuccessful, points more strongly our claim to have growing and for sale only fruit trees that will bear good fruit as soon after planting as nature's economics will permit.

We point with pride and satisfaction to some of the most successful orchards in the United States, which have been planted with our trees, and this, too, when stock less carefully grown has failed to produce good results under the very same conditions which have given profit from our trees.

Our farms, located in favorable spots in Worcester county, Maryland, include over twelve hundred acres, the best portions of which are given to nursery stock. We have extensive experimental orchards, in which we test varieties carefully under commercial conditions. Giving careful personal attention to the growing, digging and packing of our stock, we are able with confidence to commend it.

Our stock is free from all diseases and insects, and we always supply the certificate of the State Entomologist as to this important fact. Further, we make assurance doubly sure by fumigating with hydrocyanic gas before shipment.

W. M. PETERS' SONS,

WESLEY, MARYLAND. 


\section{TERMS AND Conditions.}

THE PRICES given in "this Catalogue are for the quantities named, but six will be sent at the dozen rate, or fifty at the hundred rate.

OUR TERMS ARE CASH with the order or before shipment, except by special arrangement. Large buyers may with advantage send us lists of their needs for suggestions as to cost, etc.

REMIT BY POST OFFICE MONEY ORDER on Ironshire, Md., or by Bank Draft, Express Money Order, or Check; cash sent loose in letters is at the risk of the sender. Letters may be registered when it is necessary to send cash.

PACKING IS INCLUDED in our prices, and is carefully done. The trees are delivered in good order to the railroad station at Ironshire, after which we disclaim responsibility, though we are always endeavoring to follow up shipments to destination, and find very little damage to happen in transportation. Our customers tell us our grading and packing are both superior.

PURCHASERS OF LARGE LOTS of peach trees or strawberry plants will find it greatly to their advantage to write us for special prices, as we offer discounts in our wholesale business.

IN ORDERING, please give plainly your name, post office address and state. Always tell us how you want trees to come, and name your express or freight station. Make orders on a separate sheet from your letter.

CAR-LOAD LOTS are a specialty with us, and we have shipped many large blocks of trees, peach especially, to careful planters all over the country.

WE ARE BUT HUMAN, and with all our care may make mistakes, which we are quick to correct upon notification; but we must ask to be advised within five days of the receipt of stock of any claim to be made upon any account, after which time we cannot consider them.

OUR SHIPPING FACILITIES are excellent. We are on the line of the D., M. and $V$. branch of the great Pennsylvania system, which gives us unequaled facilities for reaching shipping centers. A side-track runs directly to our packing sheds, and we load cars in the most approved modern way, without having to handle boxes or bales by wagon. We are also but two miles from Berlin, Md., where a connection is made for Baltimore direct, via Chesapeake bay.

TELEGRAMS MAY BE SENT us to either Berlin, MId, or Snow Hill, Md.

OUR GUARANTEE OF GENUINESS. While we exercise the greatest diligence and care to have all our trees, etc., true to label, and hold ourselves in readiness, on proper proof, to replace all trees, etc., that may prove untrue to label, free of charge, or refund the amount paid, it is mutually understood and agreed to between the purchaser and ourselves that our guarantee of genuiness shall in no case make us liable for any sum greater than that originally received for said trees, etc., that prove untrue.

W. M. Peters' Sons, Wesley, Md.

Dear Sirs - The trees came in fine condition, nicely packed, and all the varieties just as ordered, and I am very much pleased with them. Hance expressed himself to me in the same way. I am, very truly, JOHN SNOWDEN.
W. M. PeTERS' Sons, Wesley, Md.

Dear Sirs - I take great pleasure in thanking you for the 500 Thurber peach trees received today. They are the finest I ever saw. Enclosed find check for the same.
S. S. PENNEWILl. 


\section{PEACH TREES.}

The Peach is not a weed, and will not care for itself; it needs care, and pays for that care most bountifully. No fruit tree responds more quickly to intelligent cultivation, or more rapidly deteriorates with slipshod handling. During a recent fruiting season in a great Pennsylvania Peach orchard (grown from our fruit-bearing trees), the owner was asked: "What have you to say of commercial Peach-growing, after many years of trial, with good crops and bad, high prices and low ?" His answer was emphatic: "I am satisfied with the profit and pleasure to be had in Peach-growing, and my youngest son has just bought a farm of I5o acres to plant to Peaches." This successful grower was one of the active men, who cultivated and pruned his trees, fought the insect enemies, thinned the fruit, picked and packed with honest care, and therefore obtained profits which gave him increasing wealth and happiness.

Another notable instance is that of a Michigan grower, who cares most perfectly for his

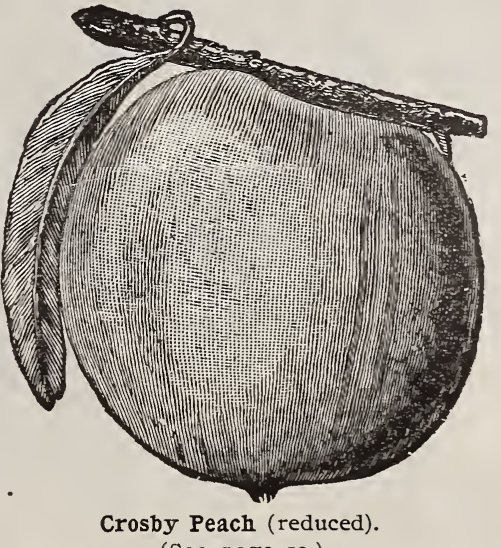
(See page II.) trees. The winter of $1898-99$ froze out most of the peaches in America; but this orchardist's trees stood the frost, and he has marketed some 6,000 bushels at from $\$ 5$ to $\$ 7 \cdot 5$ o per bushel!

The lesson is plain, and indicates that never was there a better chance for satisfactory profits from Peach-growing, if the trees are well grown and handled with intelligent care. The people of this great country are hungry for more good Peaches, and will pay good prices for them.

For our own Peach trees, we can say that they are budded from fruiting trees, on strong natural stocks, grown in land which is specially adapted. Not a trace of disease, either the dreaded "yellows" or "rosette," or of insects, from "San José" scale up, has ever appeared in our stock, and purchasers may rest assured that they will get from us the very best trees only, ready for early and profitable fruiting.

For information as to the proper handling of the Peach, we refer our readers to Professor Bailey's " Principles of Fruit-Growing," a fresh and reliable book, giving both the theory and the practice of growing, handling and marketing all American fruits. We will send it to anyone for $\$ 1.25$.

Those intending to set out large numbers of Peach trees are requested to write us freely, both for suggestions and for special prices.

W. M. Peters' Sons, Wesley, Md.

Andersontown, PA., April 12, 1899.

Dear Sirs-I received the Peach trees in good condition, and am well pleased with them. Enclosed find sixty dollars for them.

Yours truly,

ALFRED EICHELBERGER.

W. M. Peters' Sons, Wesley, Md.

ExMORE, VA., April 20, 1899. trees.

Dear Sirs-Enclosed please find check for $\$ 7.50$ as per bill for trees received. They were nice Yours truly,

W. I. Elzey.

W. M. Peters' Sons, Wesley, Md.

TOLedo, Ohio, April $14,1899$.

GENTLEMEN-Stock received in good condition, and is very satisfactory. 


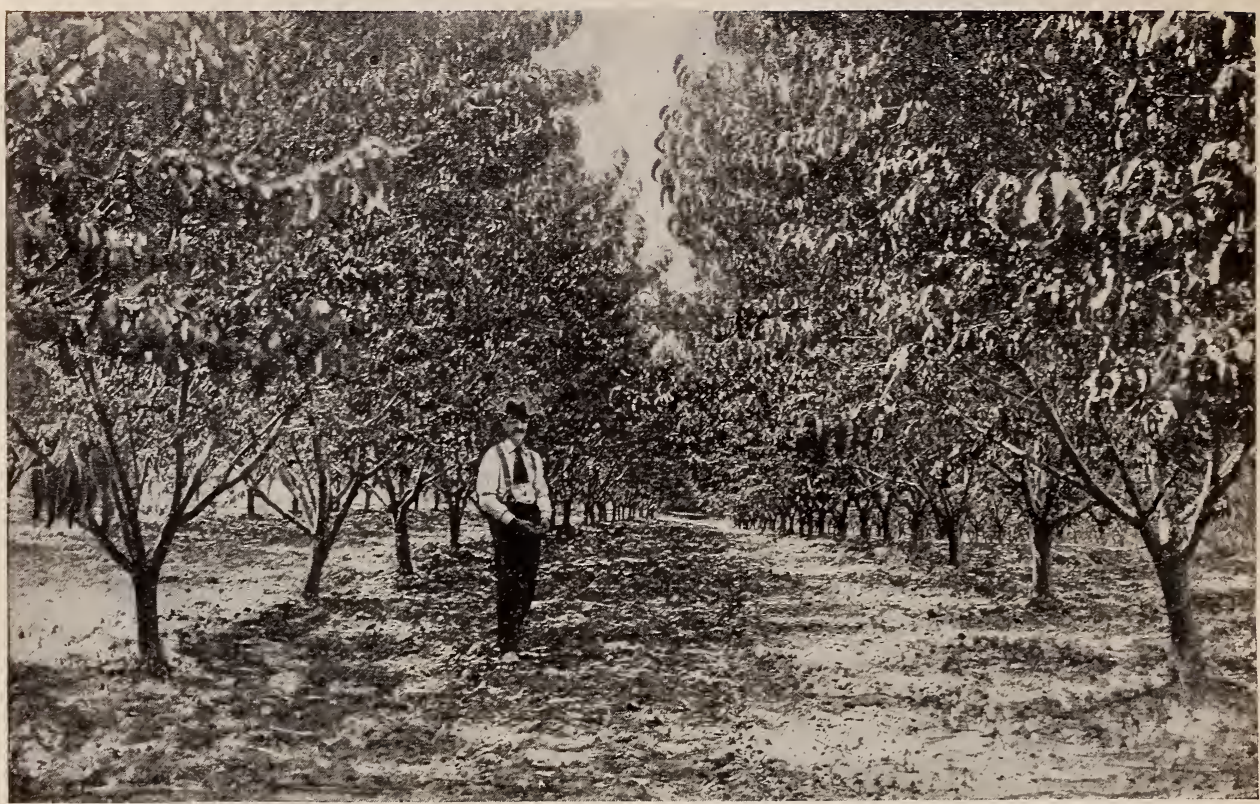

View in orchard of B. F. Cocklin, near Bowmansdale, Cumberland Co., Pa. (about 12 miles southwest of Harrisburg).

\section{How OUR Peach Trees Fruit.}

This orchard was planted in 1893. The trees are 12 feet apart in rows, with rows 20 feet apart. It will be seen in the above photograph, taken in I895, that the trees in the distance (Beer's Smock) had covered the 20 feet width. These trees were all bought from W. M. Peters' Sons.

These trees fruit, as well as grow ; from the orchard of about I,250 trees about one hundred bushels were taken in 1892 , two years after planting. In 1895 , three years from planting, the yield was nearly I,500 bushels; in 1894 , fully 2,000 bushels loaded the trees. In 1895 the crop failed in Pennsylvania, but in I 896 and I 897 the Cocklin orchard has averaged fully a thousand bushels for each year.

Thus this commercial orchard, not an "experiment farm," has given its owner fully fifty-six hundred bushels - more than eleven thousand baskets-of good fruit in seven years from time of planting. Mr. Cocklin keeps on planting, and he says the packing and grading of Peters' trees are superior, and the varieties come true to name.

MORAL.-Plant our Fruit-bearing trees, take care of them, and results will be satisfactory.

\section{"June Buds," and "August Buds."}

Peach trees are sold in two forms. June-budded trees are those which are budded early in the season on stocks of the current year's growth, and shipped the same fall or ensuing spring. They are popular among experienced planters, being easy to handle, and usually growing off very vigorously.

August-budded or fall-budded trees are worked on the same stocks as June-budded trees, and sold the succeeding year, when they are a year old from the bud. The trees are larger but no better than June buds. As we grow them, either sort will be found satisfactory, the larger trees being usually preferred by planters in the Middle states. 


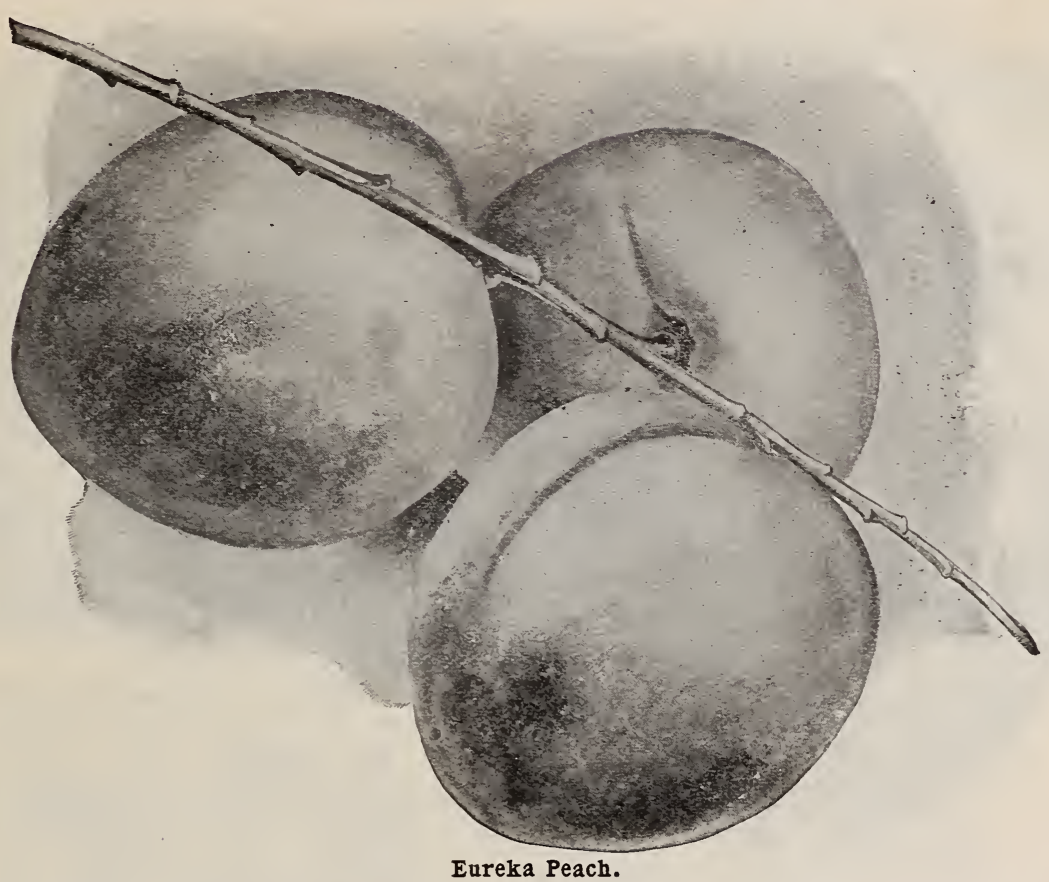

\section{THE NEWEST VARIETIES OF PEACHES.}

For general prices, see page 9.

In the past few years there has been great activity in producing new varieties, among which are some decided acquisitions. These are here described :

LORENTZ. A very late-ripening seedling discovered in Marshall county, W. Va. It is a very large freestone, yellow-fleshed, of good quality, and its handsome appearance has been a surprise to all who have seen it. It bears enormously.

BOKHARA No. 3. A Russian variety, which is claimed to be the hardiest Peach grown ; in fact it has withstood a temperature of $28^{\circ}$ below zero without injury. It is a beautiful yellow Peach, with bright red cheek; perfect freestone; delicious flavor; its exceedingly tough skin makes it a splendid shipper.

EMMA. A very large Peach, and one of the best of the freestones. It is of a beautiful yellow, with a light crimson cheek. The bright yellow flesh is fine-grained and very juicy. It ripens immediately after Elberta, and in quality is much finer than that standard.

EUREKA. The introducer proudly exclaimed, "I have found it!" when he found the first Eureka Peach, as it was the best he had ever seen. It has well sustained the claim made for it at that time. It is a seedling of Chinese Cling, of medium size, oblong; creamy white, with red blush; tender and juicy; a semi-cling, but when fully ripe almost a freestone.

FITZGERALD. This is an extremely valuable new Peach. It is of Canadian origin. Of very large size, it is at the same time of magni icent quality and a perfect freestone. One peculiarity is the extreme smallness of the stone. Its flesh is a beautiful shade of yellow, very firm, rich and juicy. It is a splendid shipper, and makes a beautiful appearance in market. Four of these Peaches weighed, upon a test, fully two pounds. It is very early in the region from whence it came, catching the market at a most opportune time.

CONNET'S SOUTHERN EARLY. A seedling of the old Chinese Cling, which originated in Guilford county, N. C. It has extra-large fruit of a cream-white shade, having a beautiful blush next to the sun. It is one of the most delicately colored Peaches grown, and a clear freestone with small seed. Of fine quality, and borne in 
PEACHES, continued.

profusion early in June upon trees noted for their strength and vigor. Introduced by the originator of the famous Elberta.

CARMAN. A new variety, which is bound to meet with favor. It is thoroughly

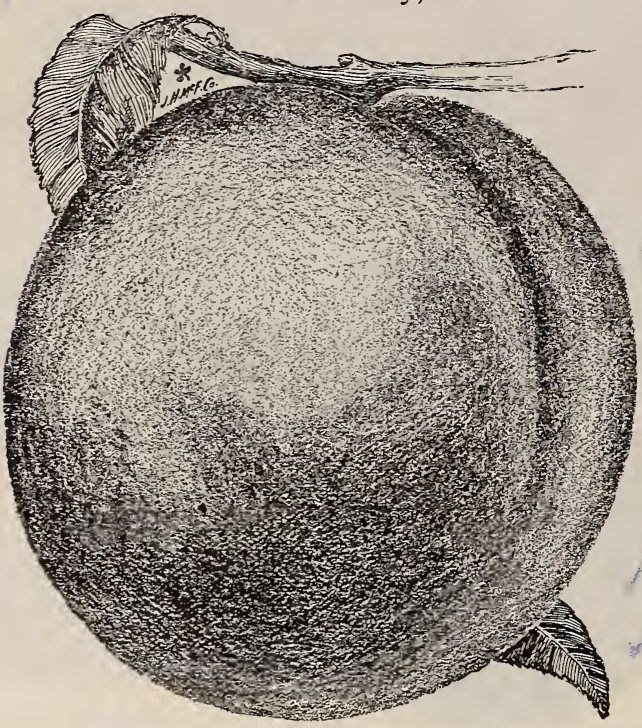

Bokhara Peach (reduced). (See page 5) hardy, rot-proof, ripens very early - at the same time as Early Rivers. It is an excellent market Peach; large and round, with a pale yellow skin, red blush on sunny side. Its flesh is white, rich, tender and melting. 20 cts. each, $\$ 2$ per doz., $\$$ Io per IOo.

WADDELL. As an early market Peach, this variety is of great value. The tree is a good, strong grower, of Chinese type, and very profuse in bearing. The fruit is medium to large, of oblong shape, and of a rich creamy white, with blush on the sunny side; of excellent quality and a very good shipper. 20 cts. each, $\$ 2$ per doz., \$Io per roo.

SNEED. See description of this fine new early Peach, on page 9.

DELAWARE. There has long been a demand for an extra-early large Peach, and in this variety, we believe the most captious will find their ideal. It is a beautiful white Peach, of good color, with a bright red blush on one side ; as large as Mountain Rose, and ripens among the earliest. It has been thoroughly tested and proved to be a variety distinct from any other early Peach. It ships in first-class condition, which makes it particularly valuable as a market variety. In flavor it is of the very best, and, coupled with its beauty and earliness, it is undoubtedly one of the most satisfactory Peaches to grow. $20 \mathrm{cts}$. each, $\$ 2$ per doz., \$IO per IOO.

HOLDERBAUM. As a thrifty, hardy Peach, the Holderbaum takes first place. It originated in the mountains of Pennsylvania, where 26 to 28 degrees below zero is of ten the temperature the original tree has stood. This hardiness is the result of the heavy bark the tree carries, and the faculty it has of ripening its wood as fast as the growth is made. It is a giant among Peaches, many specimens measuring I2 to I4 inches in circumference and is a perfect freestone, with a most delicious flavor. One peculiarity it has, of not opening out its blossoms like other varieties, makes it almost frost-proof, as the young fruit is protected by a heavy moss-like fuzz. It is a splendid shipper and altogether one of the most desirable Peaches for the fruit-grower to plant. 20 cts. each, \$2 per doz., \$IO per Ioo.

COLLINS' CLING. An accidental seedling found in the town of Snow Hill, Maryland. It is a very large white Peach, with a slight blush on one side, and of splendid quality. The flesh is fine-grained, tender and delicious. It is one of the latest to ripen and is well worth a trial.

PoCAMOKE CrTy, MD, Jan. 2S,' 99. W. M. Peters' Sons, Wesley, Md.

GENTLEMEN-It affords me pleasure to inform you that the Peach trees were the best we ever handled, and gave satisfaction to our customers. Yours truly, C. S. DAY \& Co.

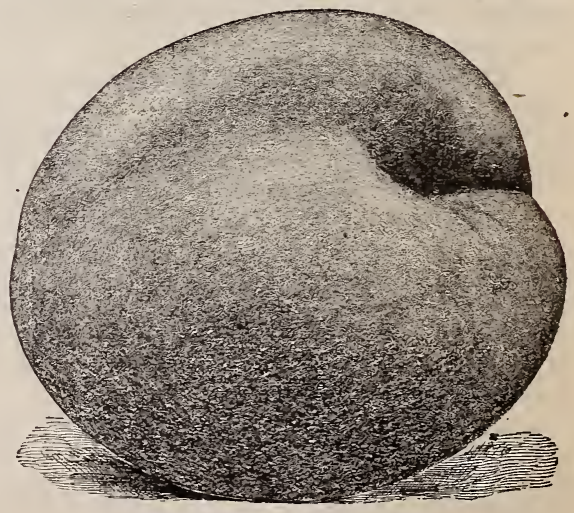

Waddell Peach (reduced). 


\section{NOW HILL NURSERIES \\ $S$ FRUIT TREES AND PLANTS $\quad \ldots 7$.

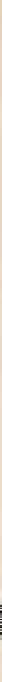

Triumph Peach.

\section{Our "Pennant-winning Mine."}

Select Varieties for Home or Orchard Culture.

(See illustration on cover.)

A perusal of our list of Peaches on the following pages will show that we are heavy growers of all the best varieties known; but there are many among our customers to whom the list does not appeal in the same manner as it does to expert Peach-growers, and to whom the long list of varieties is only confusing. For their benefit, and as a suggestion to growers who will recognize the in trinsic value of the splendid varieties here offered, we present our " Pennant-winning Nine," as displayed on the outside cover. Commencing with "Greensboro," which is the earliest of all early Peaches, the list continues through the summer in successive ripenings, until at the advent of cold weather comes "Bilyeu's Late," thus furnishing an uninterrupted supply of this most luscious fruit, and if planted in sufficiently large quantities to make blocks of each, will be found to provide good and showy fruit for marketing.

$$
\begin{aligned}
& \text { Prices, } 1 \text {-year-old trees. } \quad \text { Per } 10 \text { I00 } 1,000 \\
& 5 \text { to } 6 \text { feet, extra............... \$1 } 00 \text {... } \$ 700 \text { \$ } \$ 6000 \\
& 4 \text { to } 5 \text { feet, first-class................................ so } 6 \text { oo } 50 \text { co } \\
& 3 \text { to } 4 \text { feet, medium ....................... } 60500 \quad 4000 \\
& 2 \text { to } 3 \text { feet, well-branched, second-class......... 50 } 400 \quad 3000 \\
& \text { I to } 2 \text { feet, " " third-class......... } 40 \quad 250 \text { I5 } 00
\end{aligned}
$$

GREENSBORO. The very earliest of the early Peaches, preceding Alexander, which has always been quoted as a standard of earliness, and is an almost perfect freestone. It is beautiful in appearance, being covered with light and dark crimson shaded with yellow. The flesh is white, very juicy and of extra quality. The tree is a good grower and the fruit a splendid shipper.

TIRUMPH. One of the finest, and the first yellow Peach to ripen. The Triumph will have its finely colored fruit ready and ripe to the stone right with the old and inferior early Peaches which now afflict the market. It has a clear yellow skin, overlaid with bright red dots and blotches. The flesh is yellow, dashed with red next the stone, from which it parts readily when fully ripe. It ships in fine shape, the specimens from which our illustration is made having traveled soo miles during warm June weather, in an ordinary basket, without damage. The tree is a tremendous grower, and bears very young; even 2-year-olds have had good fruits. As it has been tested from Michigan to Georgia, and has proved satisfactory ererywhere, we feel that we are justified in most heartily commending it. 


\section{PEACHES, continued.}

MOUNTAIN ROSE. A superb, early, white-fleshed Peach, which yearly adds to its reputation as the best of its season for home or market. Of large size, it is also of fine appearance, the delicately flushed skin being brightly shaded and marked

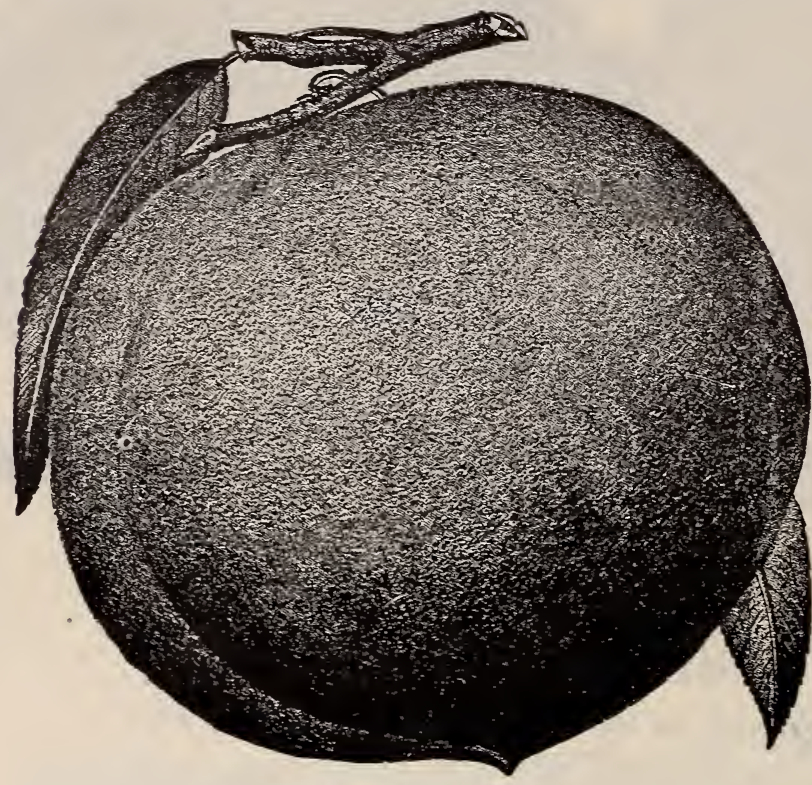

Mountain Rose. with red. The flesh is white, and parts freely from the stone; it is of especially rich flavor, with much juice. The tree is of good growth and very productive. Altogether, Mountain Rose fills a place in practical Peach growing untouched by any other variety.

CHAMIPION. A particularly hardy seedling of Oldmixon from the west, which is noted for the hardiness of its blossoms, thus insuring a good yield in spite of heavy spring frosts. It is a very large, handsome Peach, with a creamy white skin and beautiful red cheek. In flavor it is exquisite, and is a true freestone. Ripens the middle of July.

REEVES' FAVORITE. Not a new Peach, but one thoroughly tested, and with a place among knowing orchardists as one of our very best midseason yellow freestone varieties. The bright yellow skin bears on its surface a jacket of bright red; the size is large, and the shape roundish oval. The flesh is deep yellow, running into red at the stone; it is also high-flavored, juicy and melting. The tree is vigorous, very hardy, and abundantly productive.

ELBER'TA. Here is the king of market Peaches! It has been said that Elberta would not "color up" in the north, though most beautiful in its Georgia home; but those who saw it ripening in a great Connecticut orchard could certify to its brilliancy, as well as to its size and form. It is the ideal market Peach, and a royal fruit, from its yellow and red skin to its red stone, from which fall away the great half globes of superb, deep !emon-colored flesh. The size is enormous, the quality excellent, the tree vigorous and productive. Better still, the fruit market has never yet had too many of this sort, and those who plant and grow it with care will get golden dollars for golden Elbertas.

CHAIR'S CHOICE. A large and handsome late yellow Peach, with conspicuous red cheek. The flesh is deep yellow, running to red at the stone, and is of high flavor, juicy and melting; it is a freestone. The tree is hardy, vigorous and productive.

FOX'S SEEDLING. This is a native of New Jersey, where it has always proved very productive and in all respects a very satisfactory Peach to grow. It is rather late, and a good freestone. The fruit is round, slightly compressed. The skin is white with, a red cheek. The flesh is melting, juicy and sweet, and thoroughly delicious.

BIIYEU'S LATE OCTOBER. The last Peach to ripen, but by no means the least in quality. It is of large size, is a perfect freestone, and in richness of flavor can hardly be surpassed. By reason of its lateness it is a sure bearer, and the tree is remarkably thrifty and productive, bearing large crops of beautiful fruit with red cheeks. 


\section{STANDARD VARIETIES OF PEACH TREES,} One Year Old from Bud.

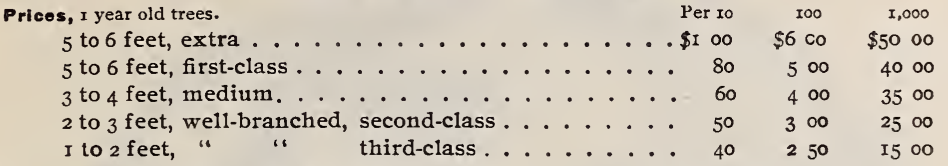

Varieties are Named in Order of Ripening.

Greensboro. See description in our "Pennant-winning Nine," page 7.

Sneed. Up to the present time this is one of the earliest Peaches known, ripening in Georgia in May. Of medium size, it is somewhat oval in shape; rich, creamy white, with beautiful red blush on sunny side. Ripens very evenly, and has a great advantage over other early varieties, inasmuch as it is not subject to rot. As an early market Peach, it is one of the most valuable grown.

Alexander. Considered one of the best early Peaches, being of large size, nearly round, with a shallow suture ; skin greenish white, nearly covered with deep red, turning to almost purple in the sun; flesh white, firm, juicy and sweet, adhering slightly to the stone, which is small.

Amsden June. Very much like Alexander. Medium size, highly colored skin and white flesh; freestone. One of the earliest.

Triumph. See description in our "Pennant-winning Nine," page 7.

Early Rivers. A large Peach of a pale straw color, with a delicate pink cheek ; flesh melting, very rich. Middle of July.

Hale's Early. A standard early sort, coming into bearing in July. Particularly attractive, with smooth, white skin, delicately marbled with different shades of red on the sunny side. Rots in some locations.

Michigan Early. A western variety which has given great satisfaction. Splendid as a market Peach, as well as for canning; hardy and prolific.

Large Early York. Considered the very best of its season. It has many synonyms, and is one of the most popular Peaches for garden cultuie. A regular bearer, of high flavor, and the tree is particularly hardy and vigorous; fruit is large and round, with broad suture; skin yellowish white, with beautiful blush; freestone. August.

Yellow St. John, or Fleitas. Called by some in the South May Beauty. A large, round, orange-yellow Peach, with deep cheek; very juicy and sweet; yellow flesh; freestone. Midảle of July in North Carolina.

Barnard's Early. A rather small Peach, but very hardy and productive; yellow, with a red cheek. Well adapted to the northern states by reason of its hardiness.

Snow's Orange. In size, appearance and general characteristics very much like Barnard's Early. Freestone.

Mountain Rose. See description in our "Pennant-winning Nine " list, page 8.

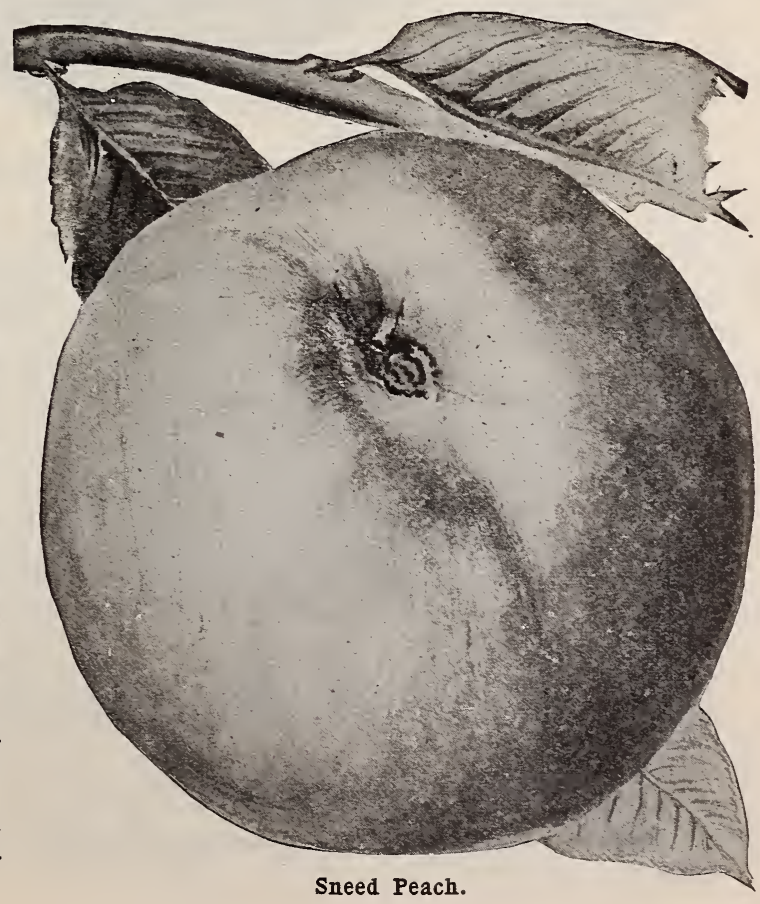




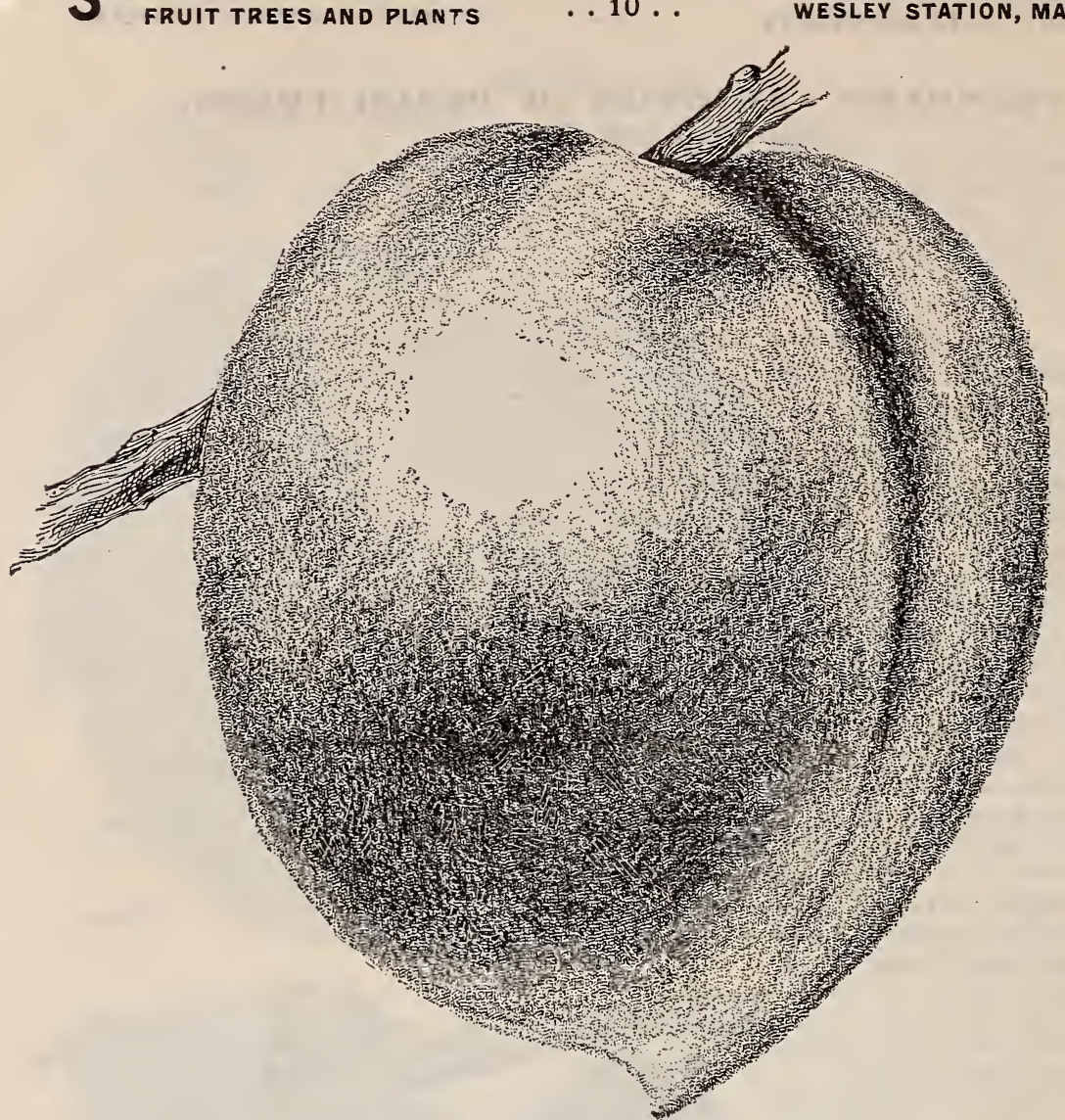

Elberta Peach. (See page 8.)

PEACHES, continued.

Champion. See description in our "Pennant-winning Nine," page 8.

Conkling. A large, yellow variety, with red cheek. Ripens a trifle later than Crawford's Early.

Foster. A good, hardy, northern Peach, originating near Boston. Very large and round, about the same as Crawford's Early (before which it ripens) in size, but of much better quality; a yellow freestone.

Crawford's Early. The true Crawford's Early, of which we have a large, guaranteed stock, is a most valuable market Peach. It is a magnificent, yellow-fleshed fruit, of large size and highly colored. This variety was almost extinct, but it has been revived better than ever. Many growers have been raising a small, yellowfleshed Peach and calling it Crawford's Early, by which they have done great injustice to this splendid fruit. Tree a moderate grower and extremely productive. Freestone.

Peninsula Yellow. One of the best bearers in the yellow family ; originated in Wicomico county, Maryland. Large when not too full; colors high, and ripens in advance of Oldmixon. Is one of the most profitable Peaches grown; best results are obtained by thinning.

Mary's Choice. Not a very heavy bearer, but makes up in quality what it lacks in quantity. Large, yellow freestone, with red cheek. Medium late in season. page 8.

Reeves' Favorite. See description in our "Pennant-winning Nine" list, 
PEACHES, continued.

Elberta. See description in our "Pennant-winning Nine," page 8.

Burke. Very large and oblong; of a pale cream color, slightly shaded with red white flesh, juicy and sweet ; very showy; clingstone. Last of July.

Chinese Cling. A favorite Peach in the southland. Medium early; of large size; creamy white, with beautiful blush; flesh of the very highest quality; indeed, the standard of richness among Peaches.

Chinese Free. Of a pure Chinese type. Large size; white, with beautiful blush; very hardy and prolific; a good freestone.

Crosby. A most dis. tinct Peach, both in flavor and habit. It is flattened in form, with a deep suture. Skin is deep yellow, flushed heavily with red. The flesh is rich, luscious and sugary. Freestone, with an exceedingly small pit. Tree is hardy and vigorous, and will stand a great deal of thinning out-in fact, it improves both tree and fruit to do it.

Moore's Favorite. Res e mbles Oldmixon, but ripens a few days earlier. Fruit large, white, with red blush; freestone. Not a heavy bearer, but superfine in quality.

Oldmixon Free. One of the old standard market sorts. A large

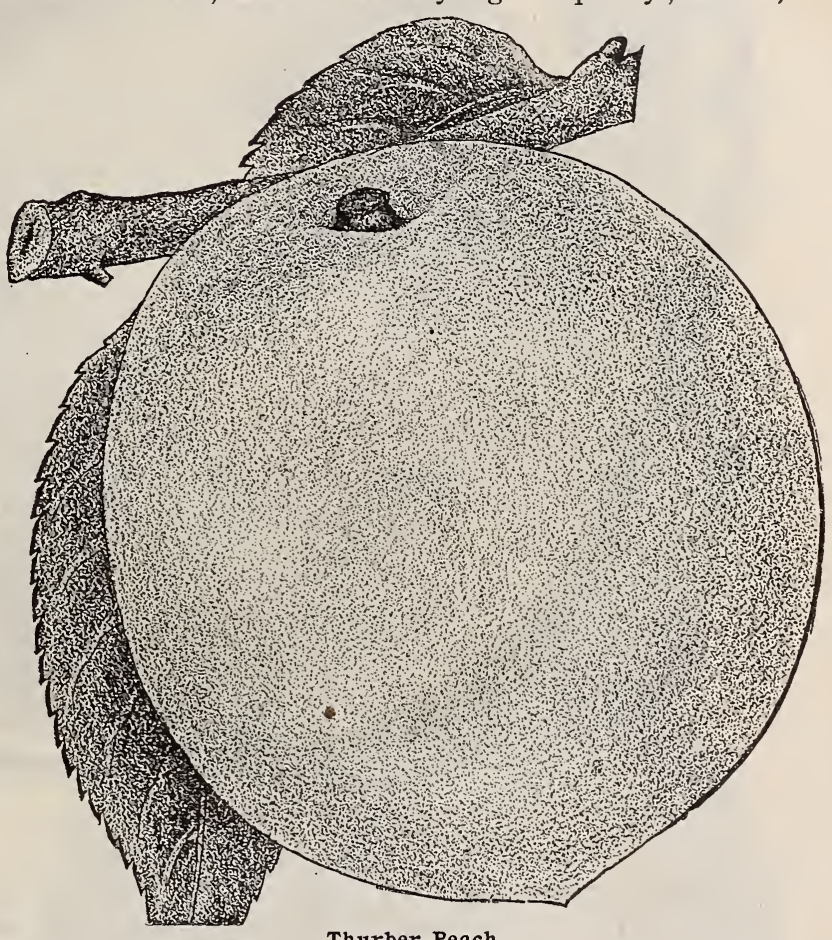

Thurber Peach. Peach, with white flesh and red cheek; a perfect freestone; very productive and profitable. Ripens just before Crawford's late.

Powell's Mammoth. As its name implies, mammoth in size; a beautiful yellow freestone, with red cheek; good in quality, with firm flesh and rich, vinous flavor. Some specimens weigh 12 ounces. Latter part of August.

Richardson's Mammoth Yellow. Similar to Powell's Mammoth, and ripens last of August. An accidental seedling found in Maryland. A large, beautiful, freestone Peach; it is of delightful flavor, and keeps well.

Red=Cheek Melocoton, or Melagatune. Almost too well known to require description. Under various names, hundreds of thousands of bushels are raised every year; and it is the parent of many of the modern varieties. Fruit is large, roundish oval; yellow skin, deep red cheek; a perfect freestone. First of September.

Stump=the=World. Large; creamy white, with red cheek. This is a highly flavored Peach, an old freestone variety, and very prolific. Resembles Oldmixon Free, and comes into bearing late.

Thurber. A seedling of the Chinese Cling, and ripe about the middle of July. Originated in Georgia. Fruit large and round, slightly oval; creamy white, shaded and mottled with pale red; fine-grained flesh, juicy and melting ; freestone.

W. M. PETERS' SONS, Wesley. Md.

Mount Sidney, VA., Dec. 2, 1898.

DEAR SIRS-The Peach trees ordered from you some time ago were received and give perfect satisfaction. Will let you hear from me again some time. 


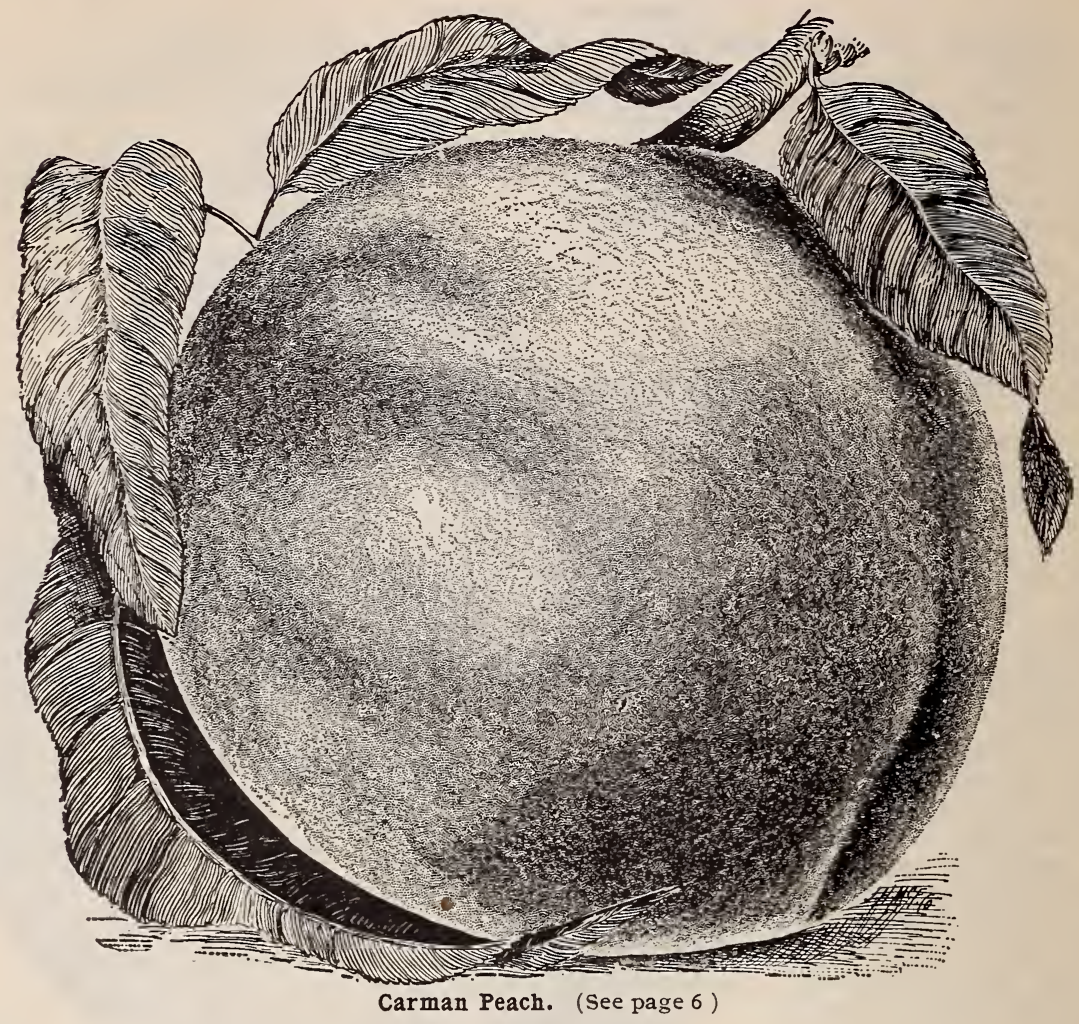

PEACHES, continued.

Engle's Mammoth. An extremely large Peach. Particularly valuable for Michigan, where it originated. A beautiful yellow, with rich red blush, and splendid, firm yellow flesh; pure freestone; rich in flavor and juicy.

Late Mixon. Very Similar to Oldmixon, but later; freestone.

Lemon Cling. A handsome, lemon-shaped clingstone, firm flesh, rich flavor.

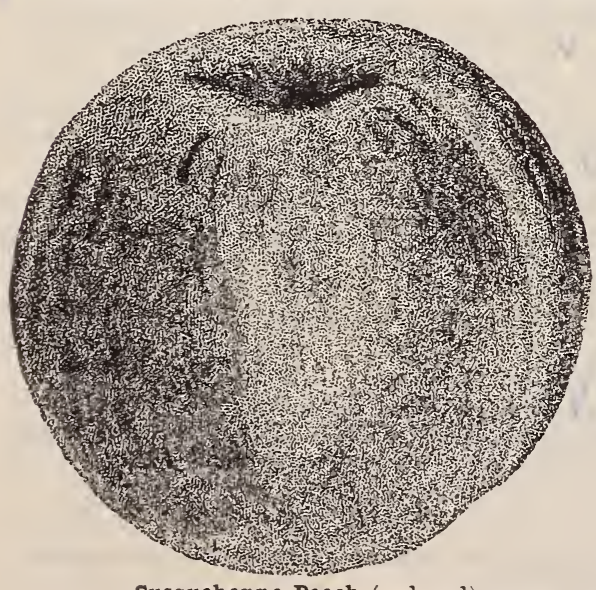

Susquehanna Peach (reduced). Ripens just before Crawford's Late.

Christiana. A southern variety, ripening in September. A very large fruit, with clear yellow skin and flesh; delicious flavor; freestone.

Susquehanna. (Called Griffith by some.) A large, handsome freestone, very popular with those who have raised it. Nearly round, with rich yellow skin and beautiful red blush almost covering it. Flesh yellow, sweet and juicy. Ripens the first two weeks in September.

Crawford's Late. A standard sort, which holds its own with the best of its competitors. Considered by some as the very best of its season, and, as a yellow-fleshed Peach, unequaled in quality. There are few Peaches which excel it as a profitable market fruit. Freestone. 
PEACHES, continued.

Wheatland. Very large, roundish; bright yellow, with a crimson cheek; yellow flesh; very firm and juicy; free, strong and prolific. September.

Wager. A very prolific, yellow freestone, ripening rather late in the season. Very hardy, and a most satisfactory Peach to grow.

Chair's Choice. A late yellow-fleshed Peach. See description in "Pennantwinning Nine" list, page 8.

Brandywine. Large, yellow, firm. A very desirable freestone Peach; similar to Crawford's Late in looks, but about one week later than that zariety. It has been well tested for years, and has always exceeded expectations.

Globe. A Pennsylvania variety of great size and beauty, and of exquisite flavor. Globular in form, all the fruit on the tree running uniformly large; golden yellow, with red blush; flesh firm and juicy, yellow, shaded with red toward the stone, from which it frees itself perfectly. A splendid shipper.

Hill's Chili Improved. This variety was first called Connecticut, and now has some thirteen different names. Of New York origin; hardy, vigorous and productive; of a medium size, oval, with slight suture; in color a deep yellow, shaded with dark red; flesh deep yellow, red at the stone, from which it parts readily. Last of September.

Hill's Chili. Of medium size, dull yellow, and a prolific bearer; a particularly good market variety. Last of September.

Prize. A very large, yellow freestone; one of the most profitable of the late varieties, and wherever it is grown is a most popular Peach.

Ward's Late Free. A good round, white, medium sized Peach, having a lovely blush in the sun. A perfect freestone, ripening after Crawford's Late.

Fox's Seedling. See description in our "Pennantwinning Nine" list, page 8.

Beer's Smock. One of the most popular Peaches grown for canning and evaporating. Very productive, and of good quality. Ripens rather late, with Brandywine.

Geary's Hold. On. Very much like Beer's Smock, but a little larger; yellow, with red blush, and a very profitable Peach to grow ; a late variety, ripening later than Brandywine.

$\mathrm{N}$ e wington Cling. An old English variety, which has the good quality of standing late frosts, thereby insuring good crops. Ripens just before Heath.

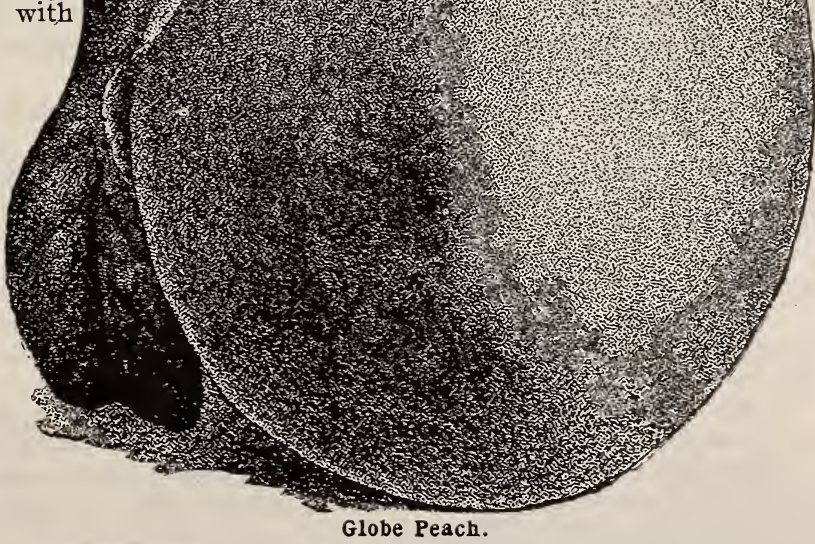

W. M. Peters' Sons, Wesley, Md.

Lexington, Mo., Apr. $18,1899$.

GENTLEMEN-I wrote you a few days ago that my trees had not come to hand; since then they were received on the $15^{\text {th }}$, just two weeks in transit. This is too long, I think, though they seem to not have suffered much.

I am delighted with the manner you filled my small order, and will follow it with others in the future. You wrote me that CARMAN was worth more than the others, but that you put it in. I did not notice at the time of sending that CARMAN was quoted among the "Special Six." 


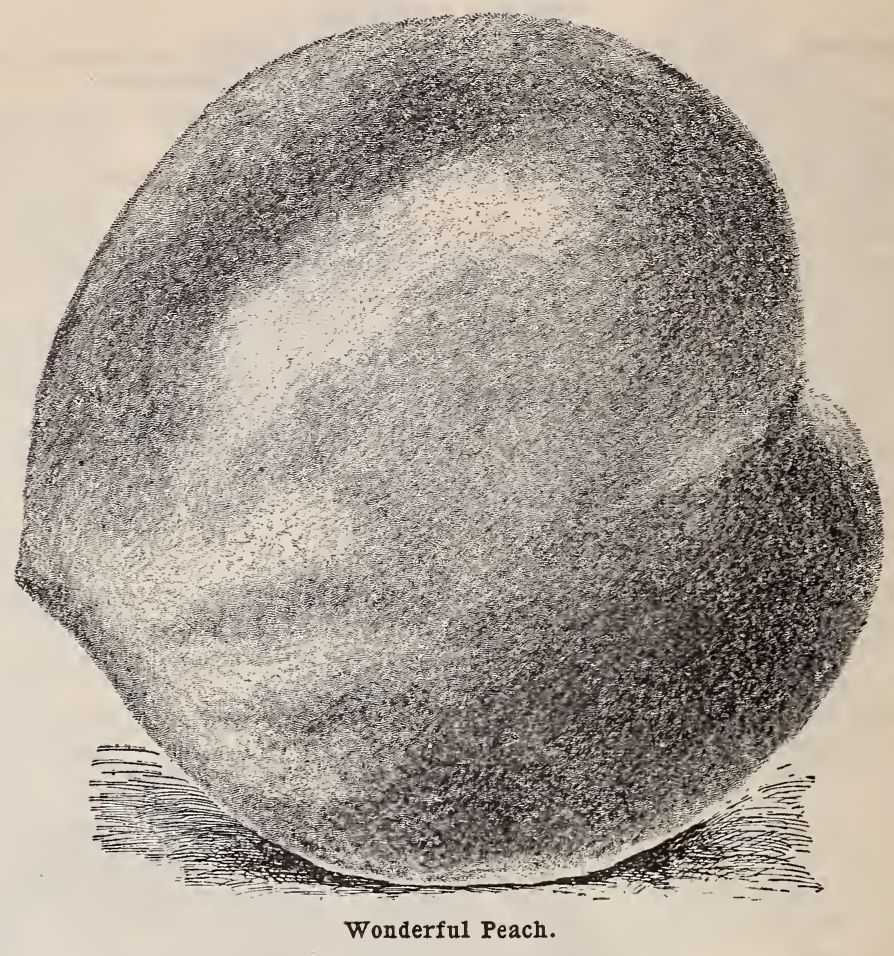

PEACHES, continued.

Salway. A rather large yellow freestone variety, which is particularly adapted to light, sandy soil. A late Peach, which comes into bearing about September I.

Nicholson Smock. A good late Peach with bright yellow flesh; handsome and large, perfectly free, and a heavy and regular bearer.

Smock Cling. A large, yellow, productive Peach, chiefly valuable for canning and preserving.

Shipley's Late Red. Large, handsome Peach, of very good quality. Follows Smock. Creamy white, with beautiful red cheek; white flesh. Very popular in Delaware and Maryland.

Steadley. Greenish white in color, with white flesh; large in size, and a perfect freestone. Ripens with or after Smock.

Wonderful. Extra large, and of a rich, deep yellow, covered with carmine; freestone; yellow flesh, firm and high-flavored; very prolific. Late September and October.

Stevens' Late Rareripe. A very popular New York Peach, which grows to immense size when thinned; very hardy. Freestone. Late.

Golden Drop. A very hardy, prolific variety. Much grown in Michigan, where it is very popular. Of medium size and bright yellow. A good market variety, ripening the first part of October.

De Corse Heath. Very large ; clingstone ; very late, and of a peculiar transparent appearance. Considered valuable in Maryland.

McCallister Late Yellow. A yellow Peach of immense size. A cross between Crawford and Smock, having the good qualities of both of these standard sorts. Very popular where grown.

Silver Medal. A beautiful, large, white freestone, white all the way to the stone; free; very hardy and prolific. Ripens with Smock. 
PEACHES, continued,

Wilkins' Cling. A seeding of Heath, but larger. Sometimes called Ringgold Mammoth. Its originator thinks it the most valuable Peach in cultivation. October.

Taylor's Mammoth Cling. A magnificent white clingstone of immense size, and chiefly valuable for preserving. Promises to be superior in every way to White Heath Cling. Last of September.

Picquet's Late. A Georgia variety, where it comes into bearing in September. Fruit is very large, sometimes lopsided; yellow, with a red cheek; flesh yellow, sweet and of high flavor; freestone.

White Heath Cling. Very large and oblong, with white skin and red blush; greenish white flesh, very tender and juicy. Very popular in the south and west, where it is extensively planted. Tree very hardy and vigorous. October.

Heath Cling. See White Heath Cling.

Henrietta (Levy's Late). A beautiful clingstone, with remarkable keeping qualities. It is bright yellow, of large size, and is very productive and excellent.

Weed's Late Barnard. A very late freestone Peach of good size and rare beauty. A good bearer on thrifty, hardy trees. A most valuable market variety.

Bilyeu's Late October. See description in our "Pennant-winning Nine," page 8.

\section{STANDARD VARIETIES IN JUNE BUDS.}

The following varieties are also furnished in June buds. All the stock is in firstclass condition, and satisfaction is guaranteed. The trees are particularly adapted for large orchard planting :

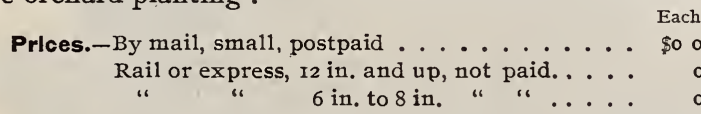
Alexander,
Crawford's Late,
Sneed,
Triumph,
Barnard's Early,
Mountain Rose,
Crawford's Early,
Greensboro,
Oldmixon Free,
Elberta,
Stump the World,
Brandywine,
Chair's Choice,
Reeves' Favorite,
Engle's Mammoth,
Globe,
Connet's Southern Early,
Champion,
Crosby,
Hill's Chili Improved,
Wonderful,
Wilkins' Cling,
White Heath Cling,
Henrietta (Levy's Late),
McCallister Late Yellow,
Ford's Late White,
Beer's Smock,
Fox's Seedling,
Geary's Hold-On,
Salway,
Amsden June,
Picquet's Late,
Bokhara No. 3 ,
Eureka,
Lorentz,
Emma,
Bilyeu's Late October,
Foster,
Fitzgerald,

$\begin{array}{rcr}\text { Doz. } & \text { 100 } & 1,000 \\ \$ 075 & \$ 300 & \\ 50 & 300 & \$ 2500 \\ 35 & 200 & 1800\end{array}$

Yellow St. John,

Weed's Late Barnard,

Stevens' Late Rareripe,

\section{Waddell, Carman.}

Special Price on Waddell and Carman, Io cts. each, \$I per doz., postpaid.

W. M. Peters' Sons, Wesley, Md.

Hammonton, N. J., March 27, 1899 .

DEAR SIRS-Peach trees duly arrived in good order, 202 trees, clean, straight, healthy stock, above contract grade; if they prove true to name, the transaction will have been entirely satisfactory.

Yours truly,

LOCK WOOD MYRICK.

W. M. Peters' Sons, Wesley, Md.

Al.ra, ILr., Nov. 18,1898 .

DEAR Sirs-The Peach trees came yesterday all right, and as nearly what we wanted as you could make it. - Trees are in good condition.

[ This was a full car-load. W. M. P.'S SoNs.] 


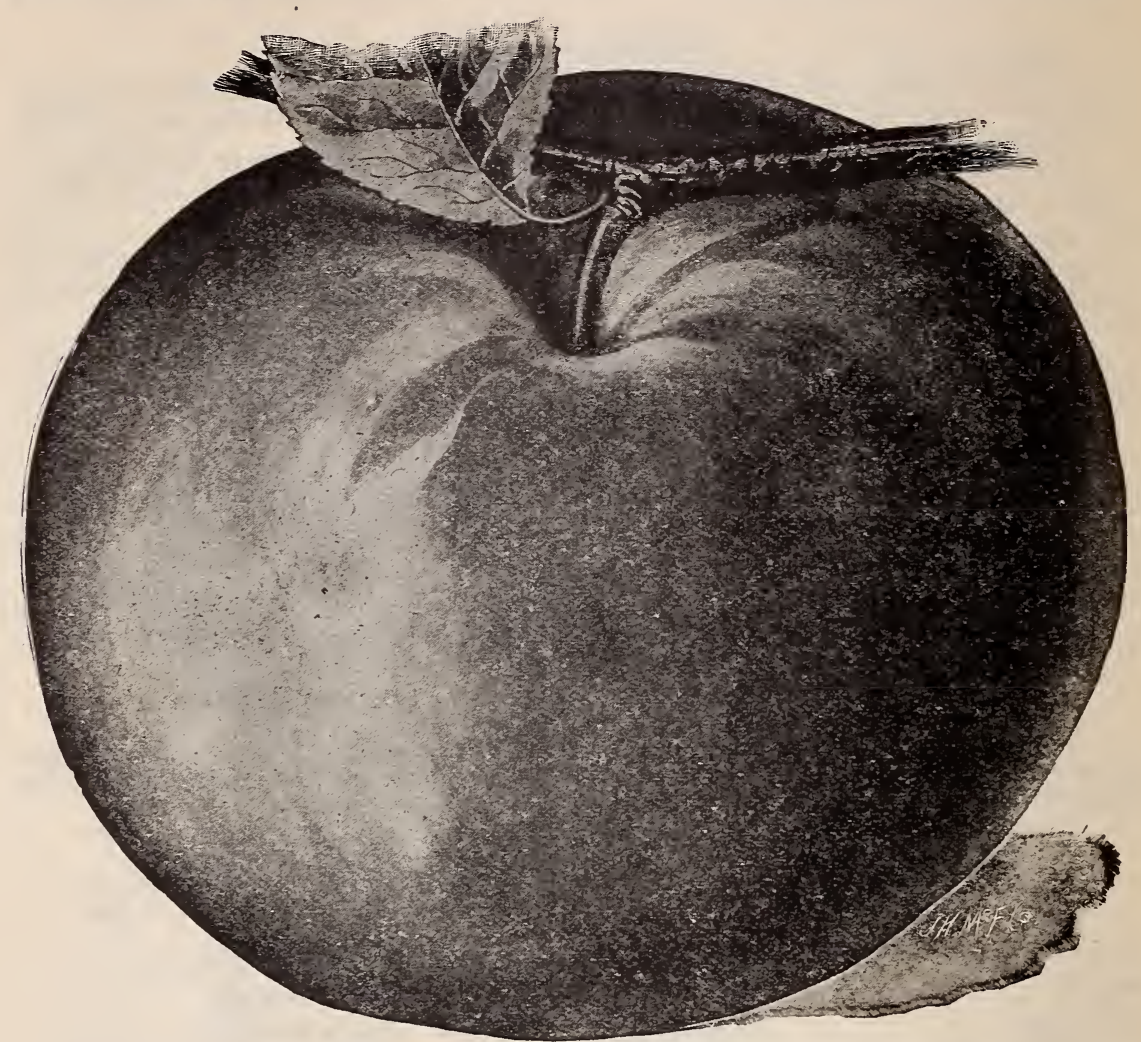

Mammoth Black Twig Apple.

\section{APPLES.}

The past few years have witnessed the shipment abroad of thousands of barrels of American Apples. There has been much profit in these shipments to growers of good fruit, and much disappointment to others. The point to be observed is that, for any market, Apples must be grown with attention to keeping the trees strong and healthy, and the fruit free from insect ravages.

Our selection of varieties is of the best only.

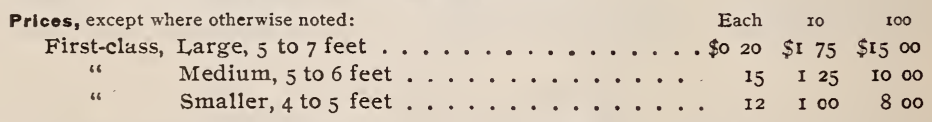

MAMMOTH BLACK TWIG. (Called Paragon by some growers.) One of the finest winter Apples grown. It originated in Lincoln, Tennessee, and is, without doubt, one of the most valuable and profitable Apples in the market. The tree is a strong grower, and makes a handsome addition to the nursery or orchard. The fruit is very large, roundish, and of a rich, dark red. We have an especially fine lot of this variety, and can guarantee satisfaction. October to February. $25 \mathrm{cts}$. each, $\$ 2.50$ per IO, $\$ 20$ per IOO.

STAYMAN'S WINESAP. A favorite cider Apple, and at the same time a valuable variety for dessert or general winter use. It is of međium size and conical form; mostly covered with red on yellow ground, and with fine, crisp flesh, with a rich, high flavor. Keeps till May. 25 cts. each, $\$ 2.50$ per Io, $\$ 20$ per Ioo. 


\section{APPLES, continued.}

BEN DAVIS. A beautiful, large Apple; greenish yellow, striped with red ; very handsome and a late keeper. It is one of the very best Apples for market-growing, and forms a staple with the great western orchardists. The tree is upright, handsome and very productive. We have a large and fine stock of this desirable variety, and commend it to all intending planters. December to March.

Baldwin. An old favorite. Large; deep red; very juicy, and of good flavor; a very heavy bearer and good keeper. November to March.

Delaware Winter (Lawver). Of medium to large size; bright red; the flesh is of fine grain, crisp and subacid; the tree is a vigorous grower and very productive. An early Apple, and a great favorite. October to December.

Duchess of Oldenburg. A Russian variety of medium size; of good shape, and beautifully striped with red; fine quality. Early September.

Dr. Noyes. Above medium size; bright, waxy red; a very handsome Apple of good quality. Tree upright and regular in form, and a good bearer. December to March here.

Early Harvest. One of the earliest of Apples. Of medium size and bright golden color; subacid and tender. July and August.

Early Strawberry. Medium size, with tender flesh of a fine, mild flavor; beautifully marked all over with red. August.

Early Sweet Bough. A very early and prolific sweet Apple of large size and oblong shape; pale greenish yellow, and of delicious flavor; tree a moderate grower. July and August.

Fallawater. A good winter Apple; very large, almost round, and of regular shape; skin smooth, of a yellowish green, with dull red cheek; flesh greenish white and fine grained. A good variety for the orchard, as it is very prolific. Can be kept till March.

Gano. Large, of perfect form, and very smooth; red, shaded deep on sunny side. A splendid shipper and keeper. The tree is strong, healthy and perfectly hardy ; an early and prolific bearer. February to May.

Grand Sultan. Very much like Yellow Transparent (see page 20) in all respects, excepting that the tree seems more vigorous and resistant to the attacks of twig blight, from which the Yellow Transparent suffers considerably.

Grimes' Golden. Of high quality. A bright yellow Apple, which grows and bears well in every section of the country; very productive. January to April.

Haas. (Called by some Gros Pomme, and Fall Queen.) Rather large, slightly conical and ribbed: of a greenish yellow, with red striping and shading; fine white flesh,occasionally stained, very tender, juicy and subacid; the tree is very vigorous and hardy, growing upright, and having a well-formed head: early and prolific. September to November.

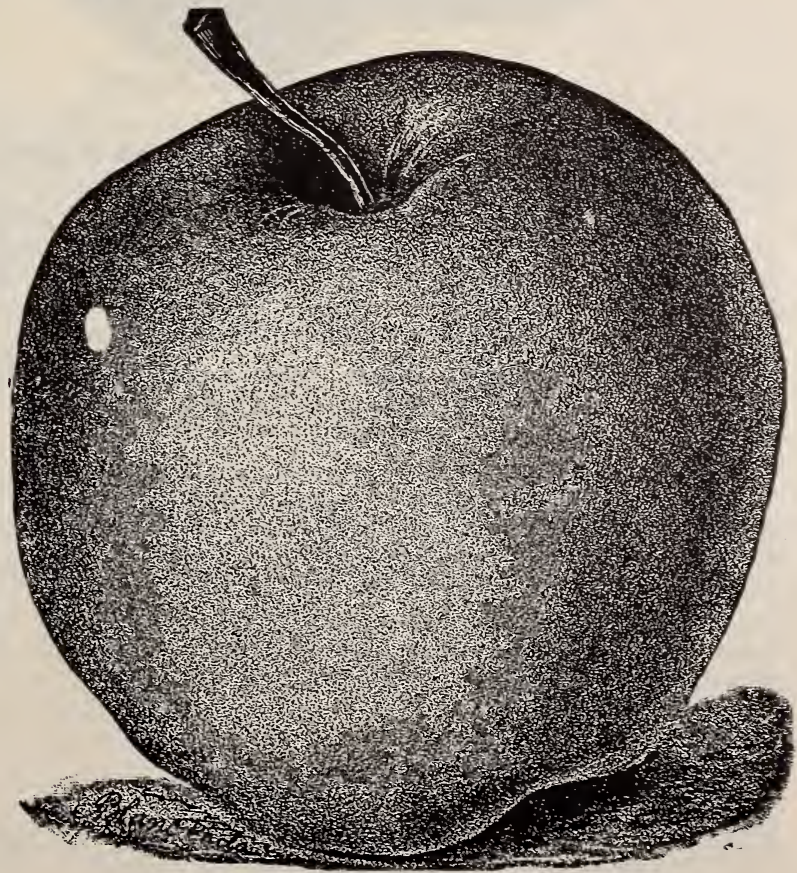

Early Harvest. 
APPLES, continued.

King of Tompkins County. A very king among Apples; of the largest size, and most beeautiful shade of red, striped with crimson ; excellent quality and flavor. The tree is a hardy, vigorous grower and an abundant bearer. December to March.

Long Island Russet. An old, well-know variety; valued highly for its cider qualities in the region from whence it takes its name. Fruit is rather small and round;

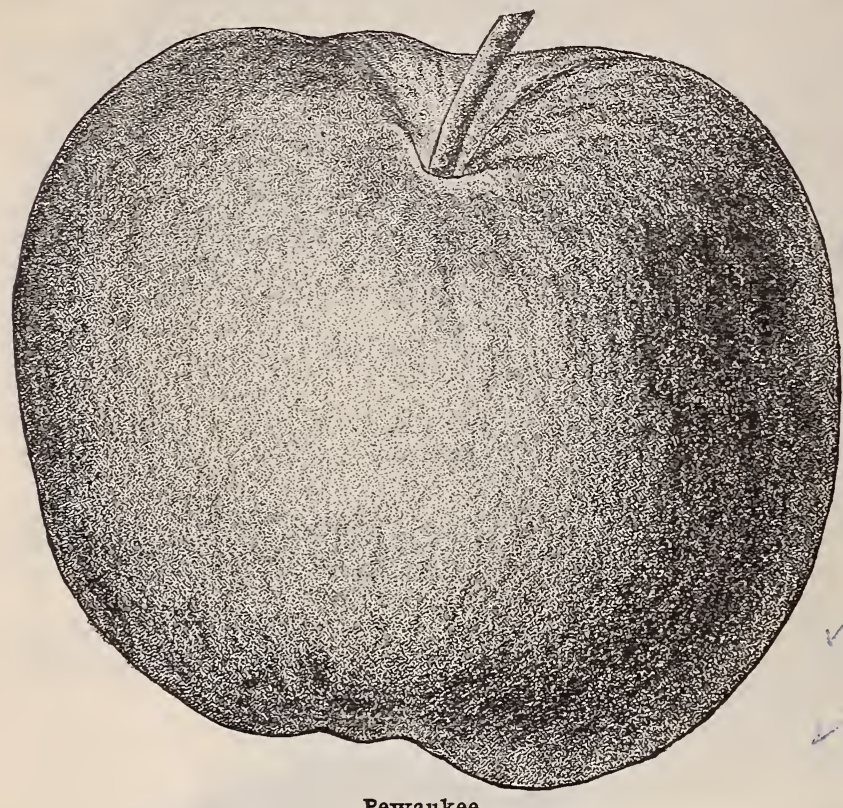

Pewaukee. yellow, overspread with dull russet, and having black spots when fully ripe; of a sweet, musky flavor; tree is vigorous, spreading and productive. October to February.

Lankford's Seed= ling. Large size; red, striped with darker shade; particularly valuable for southern growing. Tree is a splendid bearer, with fruit of excellent keeping qualities. This Apple has been kept until May and June with ordinary treatment.

Lawver. See Delaware Winter, on preceding page.

Limber Twig. A southern Apple of great popularity. Medium size, with a rich, aromatic flavor; in color is of a dark, purplish red, and is borne in great profusion upon the very thrifty trees. January to April.

Maiden's Blush. A very beautiful Apple, native of New Jersey. A most valuable variety for the table, as its brilliant color makes it a decided ornament. Particularly good, also, for drying. A handsome, rapid-growing tree, with a fine, spreading head; very prolific. Fruit of medium size and regular shape, with smooth skin ; pale lemon-yellow, with a brilliant crimson cheek. September and October.

Maryland Maiden's Blush. Above medium size when well grown; yellow, with distinct blush; flesh white, fine-grained, tender, and of excellent quality. Tree vigorous, bearing when quite young; very productive.

Nickajack. One of the best.known southern Apples, having as many as forty names in as many localities. Large, of slightly conical form ; yellowish, striped, shaded and splashed with two shades of red, often having the appearance as if covered with a thin grayish bloom. Flesh yellow and fine-grained, tender and juicy. The tree is of upright, spreading habit, forming a very large head. December to April.

Pewaukee. Medium to large; bright yellow, partly shaded with dark red. Very much like Duchess of Oldenburg, of which it is a seedling. Flesh yellowish white; tree hardy and vigorous. January to June.

W. M. Peters' Sons, Wesley, Md.

Birmingham, Ala., February 2, 1899.

DEAR SIRS - My trees, shipped by you Dec. 3 , came to hand in due time and in good order. The trees were all as fine as could be wished for. Part of the order was for some friends of mine, and they were all equally as well pleased with them, and I could have disposed of all I had, if I had not needed them myself. I gave your address to a neighbor, Mr. Geo. F. Jackson, who wants some hundred or more, and if he has not already ordered, will send one to you. Yours truly,

A. W. FULGHUM. 


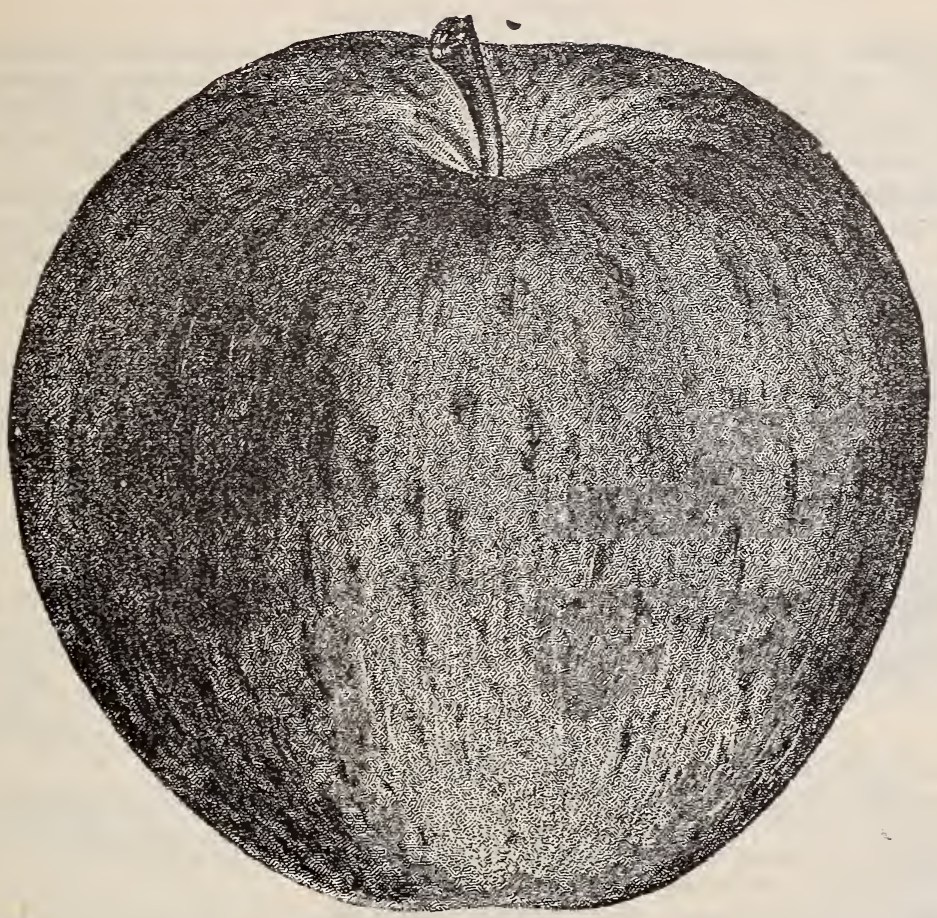

Rome Beauty.

\section{APPLES, continued.}

Rambo, Summer. One of the oldest varieties of French origin, and at one time was one of the most profitable for early marketing. The tree is hearty, growing with an open, round head. Fruit is above medium size and rather flat, of a pale greenish yellow, streaked and splashed with red on sunny side ; flesh rather soft and sprightly subacid. Early September.

Rambo, Winter. This is one of the most popular autumn or early winter Apples, and a universal favorite wherever grown. It is a fruit equally valuable for dessert or cooking, and the tree thrives well on sandy soil, being very vigorous, spreading in habit, and very prolific. The fruit is of medium size, flat and smooth; yellowish white, streaked with yellow and red on the sunny side, occasionally marked with large, rough dots. Flesh is greenish white, tender, rich and subacid. October to December.

Rawle's Janet, or Jenneting (Never-Fail, in the south). A Virginian variety, from the farm of Caleb Rawle, in Amherst county. The tree is very vigorous and spreading, coming into leaf and blossom later than most varieties, thereby avoiding injury by late frosts. Much cultivated in the south and southwest. Fruit is large and conical in shape. Yellow, shaded with red, with darker stripes. February to June.

Red Astrachan. One of the handsomest Apples grown, with a bloom on its smooth, waxy surface much like that on a Plum. The tree is a abundant bearer and vigorous in growth, upright and spreading. It is a magnificent dessert fruit, but apt to get mealy if allowed to remain on the tree after ripening. Rather large, smooth and round. Of a beautiful shade of red, occasionally running into a greenish yellow in the shade. Flesh is white, crisp and juicy, with a rich acid flavor. July and August.

Rome Beauty. A splendid Apple, thriving well in the southwest. The tree is a moderate grower and late bloomer. Fruit is large and round, somewhat conical; yellow, striped with red; flesh yellowish, tender and juicy. October to December. 


\section{APPLES, continued.}

Roxbury, or Boston Russet. As its name implies, a native of Massachusetts, where it is one of the most popular market varieties. Tree is strong, vigorous and spreading. Fruit is of medium size or large, a little flattened. Skin at first is dull green, with brownish russet when ripe, and occasionally a slight blush on sunny side. Flesh greenish white, juicy, with rich, subacid flavor. January to June.

Shockley. A southern variety of good habit; tree vigorous, upright and very productive, bearing young and regularly. Fruit medium, conical, of pale yellow,

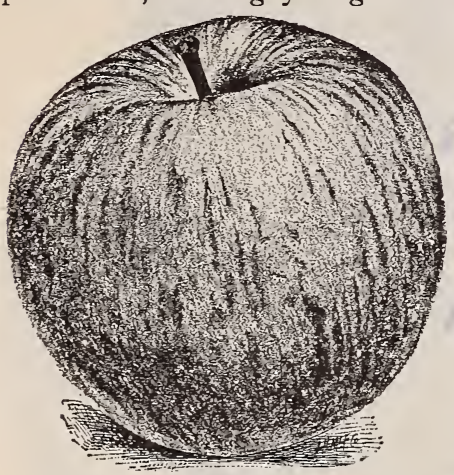

Stark. covered with minute red dots; flesh crisp and juicy. considered by Downing as one of the most profitable varieties in the south, where it sells remarkably well. April and May.

Smith's Cider. A valuable Pennsylvania variety, and much esteemed as a profitable market sort. Tree very vigorous and productive. Fruit is medium to large, irregular in shape; yellowish, striped red and slightly dotted with gray. Flesh is white, tender, juicy, crisp and pleasant.

Smokehouse. Another Pennsylvania variety, where it is very popular and well known. Tree is moderately vigorous, with spreading head, and extremely productive. Fruit is large and roundish, with yellow skin, shaded and splashed with crimson, and thinly sprinkled with large gray and brown dots. Flesh yellowish, firm, juicy and crisp. One of the best cooking Apples grown, and deserves even wider cultivation. September to February.

Summer King. Above medium to large, handsomely striped and covered with two shades of bright red ; flesh tender and very fine in quality. Tree upright, vigorous, forming a beautiful round head in the orchard; quite productive. August. One of the most valuable varieties of its season.

Stark. A very valuable Apple for southern planting on account of its large size, fine appearance and fine keeping qualities. The tree is vigorous, upright and spreading. Fruit large, round, and somewhat conical ; greenish yellow, shaded, splashed and striped with red over almost the entire surface. Flesh yellowish, juicy and mildly subacid. January to May.

Twenty=Ounce. An old favorite, with various names. Very large and showy, and on account of these qualities a valuable fruif for market. Fruit is round and slightly uneven, of a greenish yellow, splashed and marbled with purplish red; very productive. October to January.

Walbridge. A very productive Apple of excellent quality. Medium size, yellowish, striped with red. November to June.

Winesap. One of the finest cider Apples grown, both in its over-abundance of juice and its productiveness. The tree grows irregularly, but it bears early, and the fruit has the good quality of hanging late upon the tree without injury. Fruit is of medium size and oblong, with a smooth skin of a fine dark red, with few streaks. Flesh yellow, firm and crisp, and of high flavor, with the peculiar snap which makes it a favorite variety for eating. The tree is compact and vigorous and a good bearer. Winesap is a very valuable Apple, and we are glad to call attention to our fine stock of it. November to May.

Yellow Transparent. One of the earliest yellow Apples grown. Very valuable on that account, as it is ready for market ten days ahead of Early Harvest. Above medium size, beautiful in appearance, with firm flesh and crisp, subacid flavor. Tree vigorous, thrifty and a good bearer. July.

York Imperial (Johnson's Fine Winter). One of the finest Apples in existence; of medium size, shaded with crimson on sunny side, thinly sprinkled with gray dots. Flesh yellowish, firm, crisp, fuicy and mildly subacid. A splendid keeper, and equally valuable for the table or for cooking. Tree is vigorous and very productive.

\section{CRAB APPLES.}

All the leading varieties, such as Hewes' Virginia, Hyslop, Red Siberian, and Yellow Siberian. $35 \mathrm{cts}$. each, $\$ 25$ per Ioo. 


\section{PEARS.}

Our stock of Pear trees, both standard and dwarf, is particularly strong, hardy and true to name. We exercise great care in the packing, and, if proper care is taken, our stock will grow and bear with great success.

Standards of two or three years' growth are from $4 \frac{1}{2}$ to 7 feet high. Dwarfs of two years ave:age $2 \frac{1}{2}$ to 4 feet. These are the most suitable sizes for safe transporting and planting. Plant standards not less than 20 feet apart. Dwarfs will do as well at 8 to ro feet, and may be advantageously used to occupy the spaces between the standards. They have the further recommendation of being earlier than standards.

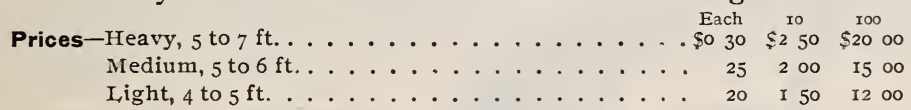

These prices apply to all but those specially noted.

\section{STANDARD PEARS.}

Anjou (Beurre d'Anjou). (Winter.) Many consider this as the best Pear grown. A splendid keeper, often being in prime condition in midwinter, when it commands the highest prices.

Angouleme (Duchesse d'Angouleme). (Autumn.) Very large; of a dull greenish yellow; very juicy and sweet.

Bartlett. (Summer.) The old standard variety, of which the people never grow tired. Its large size and rich musky flavor make it an universal favorite. Tree bears young, and is very prolific, being strong and robust.

Clapp's Favorite.(Summer.) Very large and desirable, ripening just before Bartlett. Should be picked early, or there is danger of its rotting on the tree.

Comet (Lawson of some). (Summer.) One of the largest early Pears, and particularly free from blight; a young and abundant bearer. Yellow, with crimson blush next to the sun.

Howell. (Autumn.) A large Pear, obtuse pyriform in shape; yellow, with red cheek ; rich, juicy and sweet.

Idaho. (Autumn.) One of the later sorts, of very large size and round in shape; yellow, with bronze cheek; flesh rich, melting and vinous; hardy, vigorous and productive.

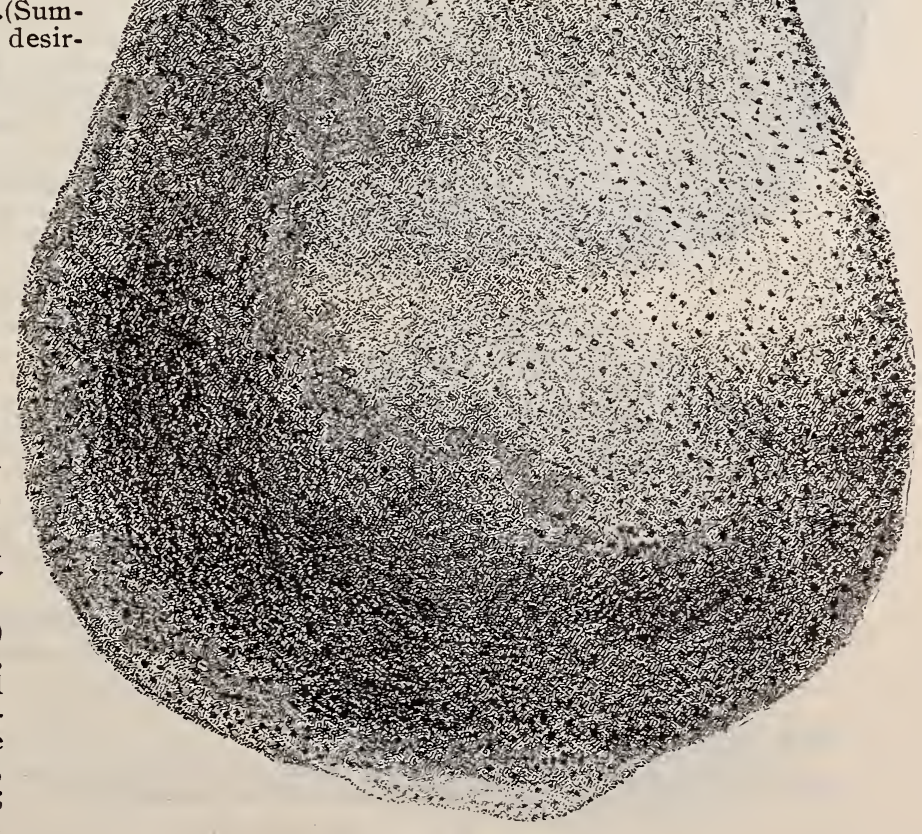

Angouleme Pear. 
PEARS, Continued.

Kieffer. One of the most distinctively shaped Pears grown, and of great vigor and productiveness. The tree is a remarkably handsome grower, and very rarely, if ever, blights. Fruil is large, richly colored, and superior for canning and for market.

Koonce. (Summer.) Very early, and similar in shape, size and color to Comet, but much better; free from blight; very productive and a strong, handsome grower. A popular variety. 50 cts. each, $\$ 3$ per ro.

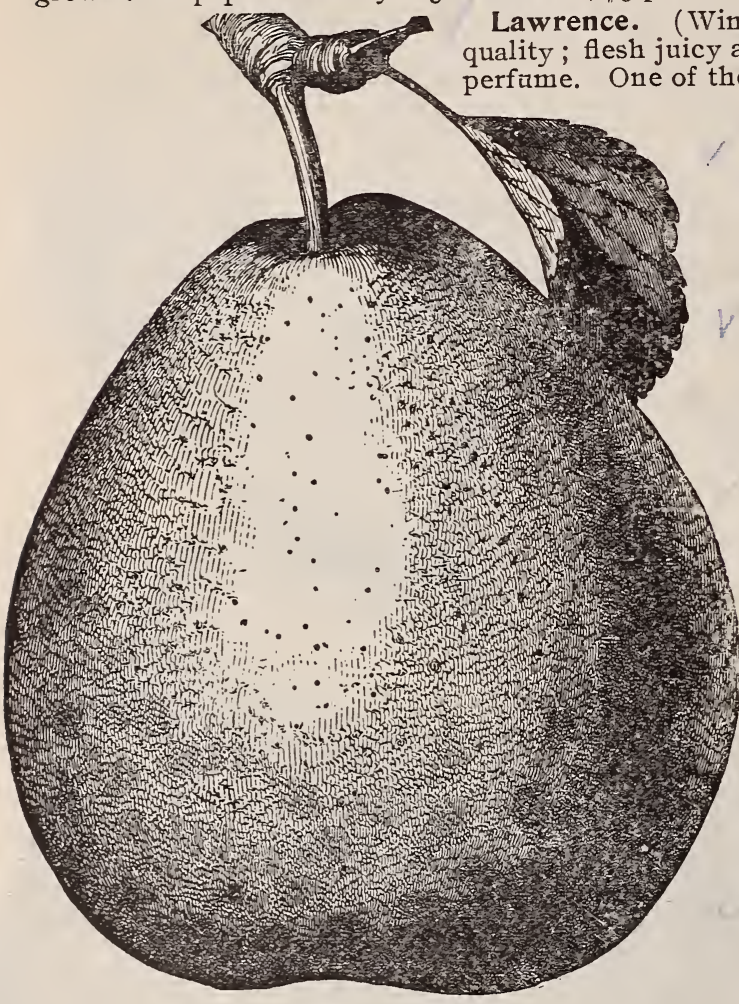

Vermont Beauty.
Lawrence. (Winter.) Not so large, but of fine quality; flesh juicy and melting, and with exquisite perfume. One of the best early winter sorts.

\section{Lawson. See Comet.}

Le Conte. (Summer.) A beautiful, smooth, yellow Pear, ripening about two weeks ahead of Bartlett; a splendid shipper and free from blight; a very prolific sort.

Manning's Elizabeth. (Summer.) This pretty little Pear makes a splendid ornament for the table; rich red and yellow in color ; small in size and borne in clusters.

Seckel. (Autumn.) This name has grown to be almost synonymous with Pear, as it is undoubtedly the best known fruit of that kind in existence. Small, but of the best and highest flavor; slow growing, very hardy and prolific.

Vermont Beauty. (Autumn.). A beautiful Pear, of medium size and good flavor; ripens just after Seckel, and is blight proof; a good annual bearer. $50 \mathrm{cts}$. each, $\$ 3$ for Io.

Winter Nelis. (Winter.) One of the old standards; of a dull russet, with rich, sprightly and melting flesh; tree a free grower and an abundant bearer.

\section{DWARF PEARS.}

All our Dwarf Pears are set on quince stock, and come into bearing sooner than the standards. Strict attention to them and high cultivation will result in magnificent yields of fruit.

Prices-Two to 3 years old ....... $25 \mathrm{cts}$. each, $\$ 2$ per Io, $\$ 15$ per Ico.

We have on hand good, thrifty trees of the following varieties, descriptions of which will be found under Standard Pears :
Anjou,
Angouleme,
Howell,
Lawrence,
Manning's Elizabeth. Seckel.

W. M. Peters' Sons, Wesley, Md.

Bolar, VA., April 12, 1899.

Gentlemen-The trees ordered of you arrived in good condition, and I found them larger and better than I expected. When in need of trees in the future will order of you. 


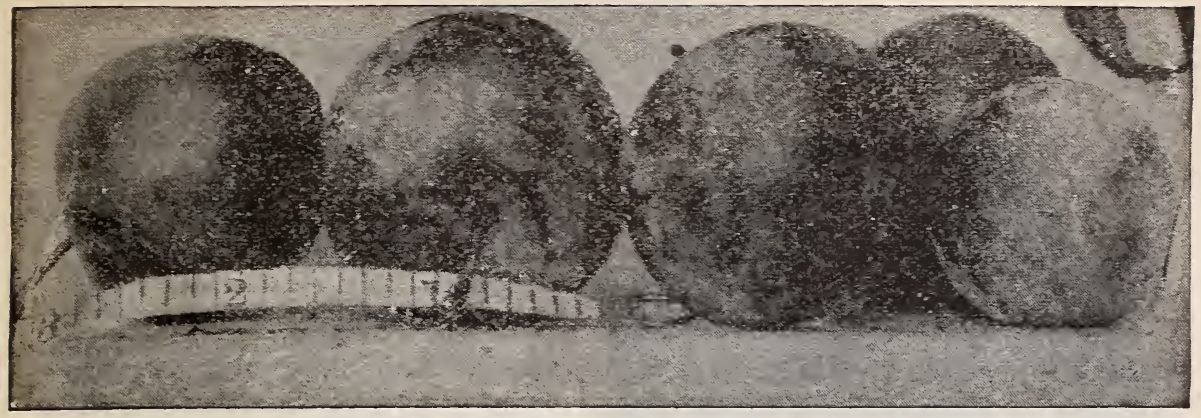

Abundance Plums.

\section{PLUMS.}

Plums have always been considered hard to raise in this section of the country, but since the introduction of the Japanese varieties they are as easy to grow as peaches, requiring about the same general treatment. Our Ylums are worked on both peach and plum roots; those varieties marked with an asterisk $\left(^{*}\right)$ can be furnished either way.

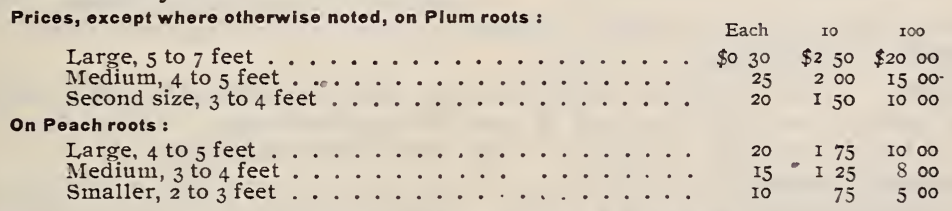

JAPANESE VARIETIES.

*Abundance (Botan of some growers). Of medium size, round, with slight point; beautiful shade of red over yellow body; flesh yellow, firm and juicy, with a slightly subacid flavor; skin is rather tough, making it a good shipper; clingstone ; very prolific. Ripens early in July.

Bailey. Large, nearly globular, with slight tendency to become conical; color rich orange, overspread with bright cherry-red, showing many minute orange dots ; flesh yellow, thick and melting, and of excellent quality ; clingstone. Tree strong, upright, and very prolific. Ripens early in July.

Botan. Called by many Abundance, and it is so nearly like it that the same words describe it fully.

Berckmans. Above medium size, broadly conical; of a beautiful deep blood-red, with rery street flesh, moderately juicy; excellent quality. Some authorities claim it as the best. Very prolific. Ripens first of July.

*Burbank. A beautiful, large Plum, of roundish conical form, with blunt point; ground color orange, thinly overlaid with red, and showing many orange dots; flesh firm and meaty, yellow, rich and sugary. One of the standard varieties, and a most valuable one. Ripens from middle of July to first of August. A good shipper.

Chabot. Medium to large and oblong conical in shape; of a beautiful light red, with many bright golden dots ; very productive ; an excellent variety for drying. Ripens early in Sept.

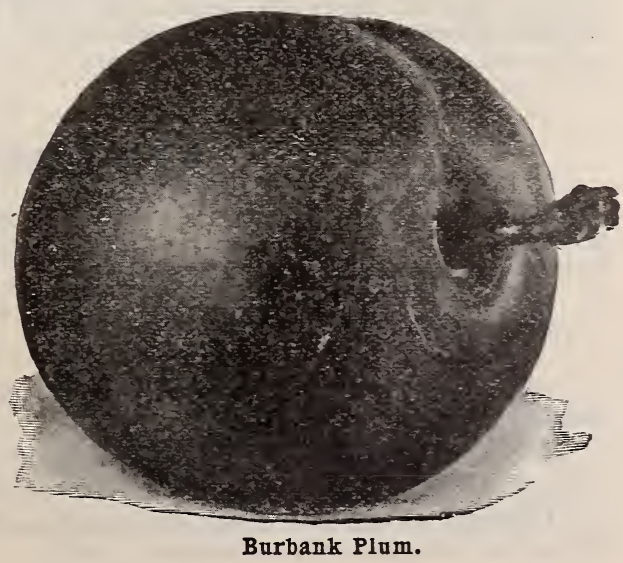


PLUMS, continued.

HALE. One of the most satisfactory Plums under cultivation, and rapidly growing in popular favor. Large in size and round; of beautiful golden orange,

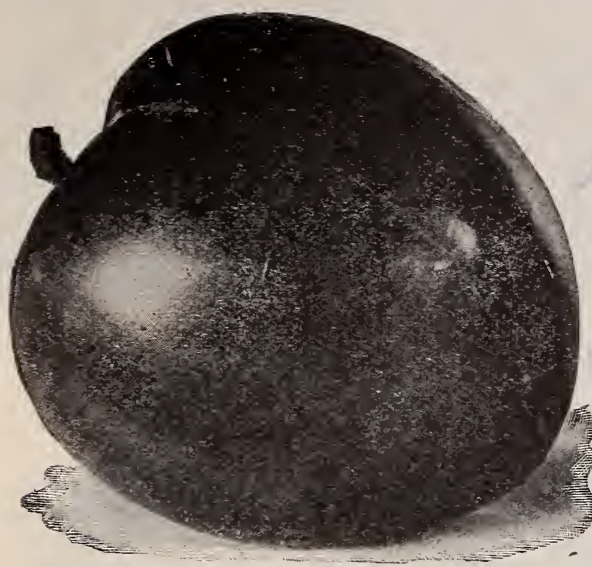

Chabot Plum. (See page 23 ) thinly overlaid with mottled red, giving it a yellowish red appearance ; flesh yellow, soft and juicy ; flavor delicious ; a splendid keeper and shipper; clingstone. Ripens very late. Special price, 50 cents each.

Kelsey. Very large, heart-shaped, with deep suture; somewhat lopsided. Of a rich, royal purple, on yellow ground, beautifully dotted; flesh light yellow and firm, with rich, pleasant flavor; freestone.

*Ogon. Medium in size, rather flat on ends; lemon-yellow, with creamy bloom; flesh thick and very meaty; freestone. A splendid keeper and shipper. A good canning variety, ripening about August I.

Red June. Medium to large in size, decidedly conical, with deep suture; of a beautiful, deep vermilionred, with handsome bloom; flesh light yellow, firm and rather juicy, sprightly subacid; half cling, with small pit. Ripens ahead of Abundance.

*Satsuma. A very large, beautiful, dark red Plum, with blood-red flesh, rather coarse in quality, but very firm and of good flavor; freestone. One of the best keepers, and an exceedingly valuable sort, ripening late in the season.

Shropshire Damson. A great improvement over the old Damson, it being the largest of its class, of a rich, dark purple. Particularly valuable for preserving. Tree is very vigorous and enormously productive. September.

Wickson. Remarkably handsome, very large, and of a deep maroon-red; one of the hardiest; flesh amber-colored, firm, meaty, and clinging to the pit, which is small. One of the most desirable Plums, either for home use or market.

Wild Goose. Of medium size, oblong, and of a bright vermilion; very juicy and sweet; a clingstone, but of excellent quality, and very productive. Nearly proof against the curculio. One of the most profitable varieties, especially in the South. July.

Willard. One of the earliest Plums, of medium size, and rather oblong in shape. Of a beautiful claret-red, covered with minute golden dots. The tree is particularly strong, vigorous, hardy and productive. Will keep two or three weeks after picking. A good shipper and valuable market variety. Special prices, on Plum roots only, 50 cts. each, $\$ 3.50$ per $\$ 10, \$ 30$ per 100 .

\section{Quinces.}

Plant Io to I2 feet apart each way. Under favorable conditions this is a most profitable fruit. Heavy manuring, clean cutting and judicious spraying will all tend to the production of heavy, perfect crops.

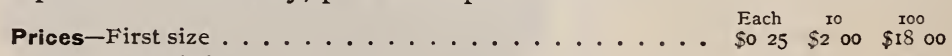

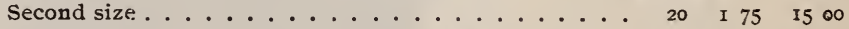

Champion. Very large, showy, and free from lumps. Tree a heavy bearer, strong and vigorous. Late.

Meech's Prolific. Medium size ; tender, smooth, bright yellow ; very productive; a variety which is coming in to great favor.

Orange, or Apple. Large and round, and of a bright yellow. One of the best known and most widely cultivated. Late. 


\section{Select Cherries.}

The Cherry succeeds on most soils and in nearly all localities throughout this country, but attains its greatest perfection upon those of a light, gravelly or sandy nature, provided they are in good condition. In planting Hearts and Bigarreaus, avoid wet or damp situations. The Dukes and Morellos will bear more moisture, but will flourish best in a soil that grows the others to the greatest perfection.

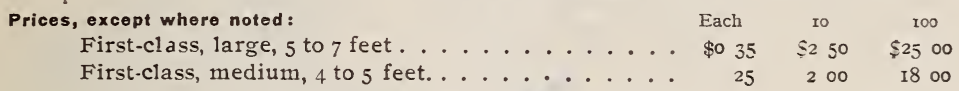

\section{MEART AND BIGARREAU CHERRIES.}

Bigarreau, or Graffion (Yellow Spanish). Very large; pale yellow, with red cheek; flesh firm, with a fine, rich flavor. July.

Black Tartarian. Fruit of the largest size; flesh dark, half tender, rich, nearly destitute of acid, of fine flavor. A general favorite. June.

Coe's Transparent. Medium size; pale amber, reddened in the sun; flesh tender, melting and juicy, with a delicate flavor; very productive. Beginning of June.

Downer's Late Red. Medium size; light red, amber in the shade; flesh tender, with a very high, sweet flavor. A good late sort. July.

Elton. One of the fincst Cherries; fruit large, pale yellow, blotched red; flesh firm, becoming tender, juicy, rich and high flavored; very productive. May and June.

Early Purple. An exceedingly early variety; fruit of medium size ; dark red; flesh purple, tender, juicy, rich.

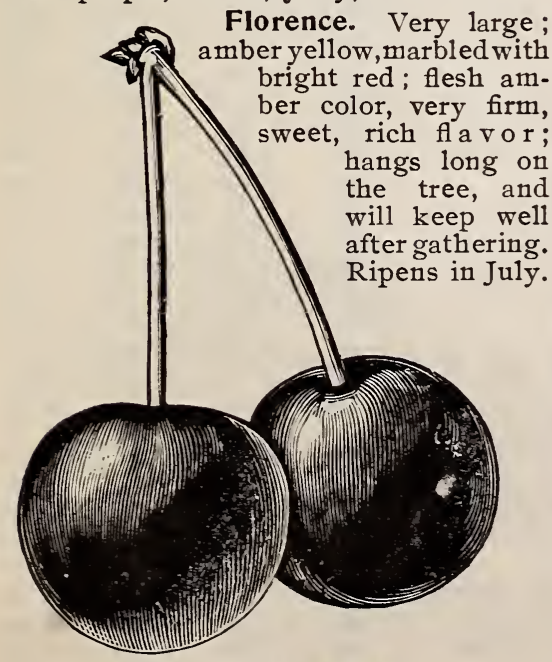

Black Tartarian Cherry.
Governor Wood. Fruit large ; skin yellow, shaded red; flesh nearly tender, juicy, rich ; tree vigorous. June.

Napoleon Bigarreau. Is one of the best of the firm-fleshed Cherries; it is of the largest size; well flavored; skin yellow, dotted red; flesh firm, juicy, good flavor; profitable for marketing June.

Rockport Bigarreau. Large ; deep red ; flesh rather firm, juicy, sweet, rich, excellent flavor; a very desirable and profitable Cherry. Beginning of June.

Windsor. Origin Canada ; fruit large, liver-colored; flesh firm and of fine quality; tree very hardy; a valuable late variety. July.

\section{DUKE AND MORELLO CHERRIES.}

The Dukes and Morellos are not so upright in their growth as the Hearts and Bigarreaus, forming low, spreading heads. The fruit is acid or subacid.

Dyehouse. In hardiness and general appearance it resembles Early Richmond, but is of finer quality and several days earlier; fruit medium; skin bright red, darkened in the sun; flesh soft, juicy, tender, sprightly, subacid, rather rich in flavor.

Early Richmond. Medium size; red; flesh melting, juicy, and at maturity of a rich acid flavor; very productive : fine for cooking. Commences ripening in May; hangs long on the tree.

May Duke. Medium size; dark red; melting, rich and juicy ; an old and popular sort.

Montmorency, Large=fruited. Fruit large, and the finest flavored of any in this class; tree a free grower, hardy and prolific.

Olivet. Of the Duke class. Large, globular, very shining, deep red; flesh red, with rose-colored juice ; tender, rich, sweet, subacid flavor. It ripens in May or early in June. It possesses the fertility of the Duke tribe, and is perhaps the largest of that class. 


\section{Strawberry Plants.}

Well-rooted, from new beds. Roots straightened and tied up, fifty in a bunch.

We now pack Strawberries in light, strong baskets, using only young, well-rooted plants, from which all dead leaves and runners have been removed. After being carefully straightened they are placed in baskets with roots in moss, and leaves exposed to the air. The baskets are then so secured that they can neither heat, lose out, nor be broken in handling. Strawberry plants so put up will keep in perfect condition for at least two weeks. They should not be wet or unpacked until ready to be used unless they are to be kept over one week, when they may be unpacked and trenched carefully.

Those marked (P) have pistillate or imperfect blossoms, and must be planted near some variety with perfect blossoms, to fruit them. We will furnish 6 of a kind at 12 rate, 50 or over at IOo rate, 500 or over at $\mathrm{I}, 000$ rate. We will be pleased to hear from those desiring to purchase Strawberry plants in lots of 20,000 and up, and to quote special prices thereon. We can make it an object to the buyer.

\section{PRICE=LIST .}

The letters in front of ndmes represent the number of plants of each variety we have, and are to be read as follows: $\mathrm{L}, 3,000$ to 5,$000 ; \mathrm{M}, 25,000$ to 50,$000 ; \mathrm{H}$, IOo,000 to 300,000 .

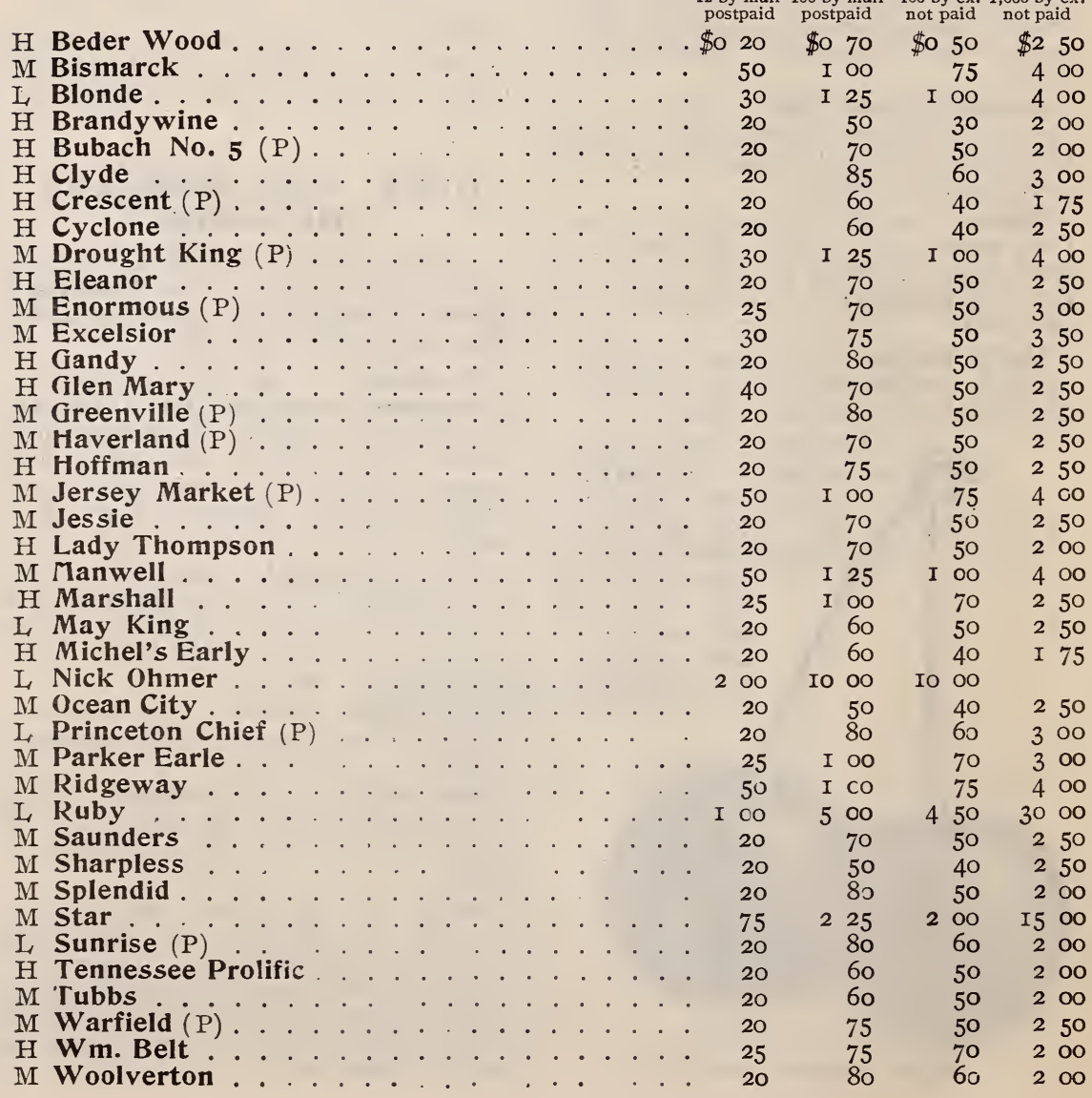




\section{DESCRIPTIONS OF STRAWBERRIES.}

Beder Wood. A large, firm-fleshed berry ; early, and of good color and form ; plant strong and prolific.

BISMARCK. A magnificent self-fertilizing Strawberry of wonderfully large

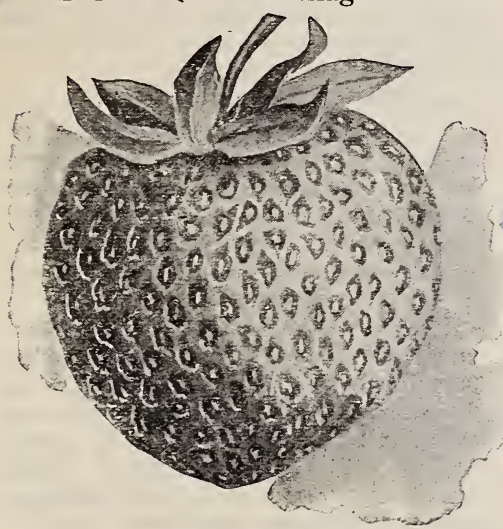

Brandywine Strawberry. size and of the finest quality. It is a beautiful, glossy red, and of good shape. The plant is a most vigorous grower, and such an abundant bearer that the originator said his patch "looked just as if some one had thrown berries over the ground with a shovel."

BLONDE. A brilliant and attractive heart-shaped berry of large size and splendid quality. A strong grower and very productive variety. Supposed to be a seedling of I Iaverland.

Brandywine. A good Pennsylvania herry; well adapted for canning. Large; deep scarlet; late.

Bubach No. 5. (P.) Large, round and conical; bright scarlet; flesh firm and good. Medium early, when the plants bear $1 \mathrm{mmense}$ crops.

CLYDE. One of the most wonderful berries ever grown. Hale says: "Clyde is the one great business Strawberry basket-filler, money-catcher, debt-destroyer, and family provider. Plant the Clyde, make money, grow fat and be happy;" and he knows. One great feature about it is its adaptability to all parts of the country, and it everywhere produces wonderful crops of large, bright scarlet, firm berries, which stand shipping splendidly and bring the best prices in market. The foliage is light green and very vigorous and handsome.

Crescent. (P.) Medium to large, conical; bright scarlet; plant hardy, vigorous and extremely prolific. One of the old standbys.

Cyclone. A general favorite wherever grown. A healthy and thrifty grower, bearing immense crops ; fruit large, bright scarlet, long and conical.

DROUGHT KING. (P.) This berry is so aptly named that it seems like repetition to refer to its drought-standing qualities. It is immensely productive and one of the earliest berries in the market. It is a splendid red, and remarkably rich, tender and full-flavored. A good shipper, the fruit keeping in perfect condition five days after picking.

Eleanor. A Jersey berry of great value. Very early and prolific, the last berries on the plants being as large as those first picked. Bright, healthy color clear to the tip.

Enormous. (P.) Comes into bearing with Bubach. and is very much like it. Its name tells the story of its size. Brilliant in color and extremely productive, lasting a long time.

EXCELSIOR. A splendid berry and very productive. Fruit is large, solid and of exquisite flavor. Extra early and a good shipper.

Gandy. Considered by many the standard late berry for market or home use. Gives thre or four heavy pickings when other crops are done. Very high quality and good bearer; succeeds everywhere.

Glen Mary. Of Pennsylvania origin, and of great value. Of very great size, a quart measure holding but 12 berries upon a recent trial.

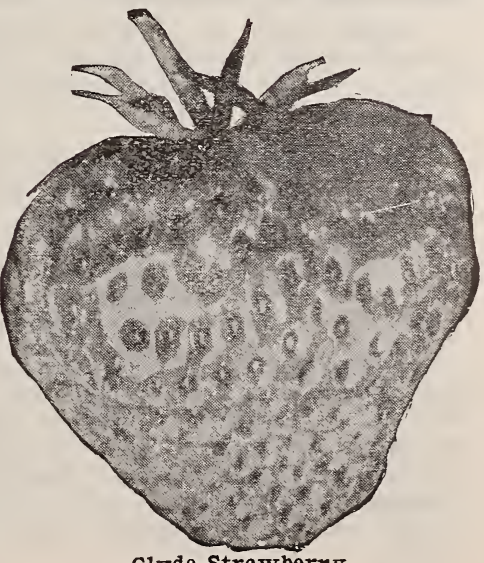

Clyde Strawberry. 
STRAWBERRIES, continued.

Greenville. (P.) Some consider this berry an improvement upon Bubach, being of firmer texture and finer in color. It is a great grower and good bearer.

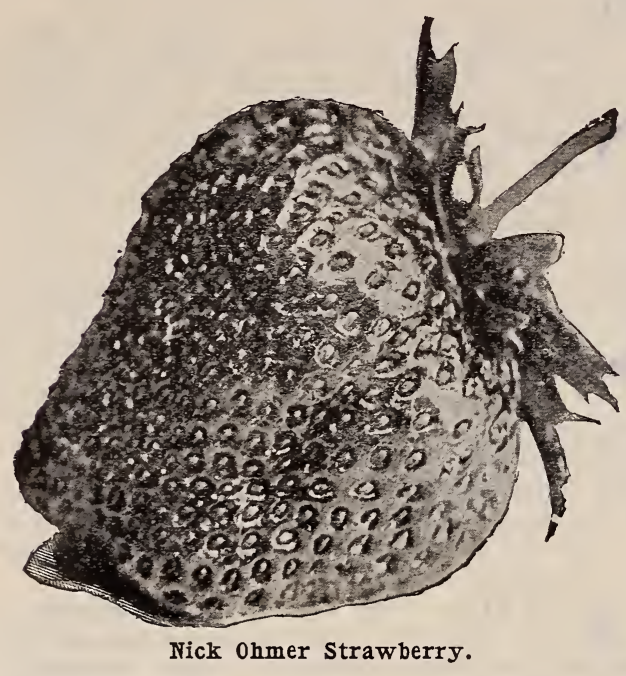

Haverland. (P.) One of the best market berries; early and very productive. The berry is large and rather pointed, and of beautiful color, firm and of high flavor.

HOFFMAN. Claimed by some to be the most profitable berry for southern growers. It is of very vigorous growth and extremely productive. The plant makes very many runners, and the berries are large, showy and firm. A good shipper, and early in the market.

JERSEY MARKET. (P.) A beauful, bright crimson berry, of moderately large size, and very uniform as to shape and color. The plant is of strong, healthy habit and a heavy yielder. It is distinctively a "business berry," and will yield large returns for the care bestowed upon it. Midseason.

Jessie. A highly colored berry of excellent quality, succeeding best in heavy and stiff soils of high fertility.

Lady Thompson. Large, immensely productive, and has the healthiest kind of foliage. A wonderful berry in every respect.

MANWELL. One of the best shipping berries grown, for the reason that it clings to its hull with great pertinacity. Very firm, of large size, and a beautiful, glossy crimson. Very prolific, as many as 20 berries growing on one stem.

Marshall. Very large; of a rich dark crimson to the core; fine grained flesh of exquisite flavor; remarkably fine keeper and carrier.

Michel's Early. An extra-early berry ; very valuable for southern growing. Plant healthy, vigorous and extremely productive. A good shipper.

May King. Very much like Crescent, but considered an improvement upon it. Bright, clear scarlet, and of good form and texture; foliage strong and healthy.

NICK OHMER. A very large, strong, vigorous plant, bearing wonderful crops of dark, glossy red fruit, of firm texture and splendid flavor. In size it is a veritable giant among Strawberries, and a splendid shipper.

Ocean City. A beautiful berry, of uniform size and shape; a stout, vigorous grower and an abundant bearer. Berries are large, solid and of good quality; very rich and sweet.

Parker Earle. Undoubtedly one of the best berries grown for home or market. A standard by which other berries are judged. Large, long. regular in shape and uniform in size; flesh firm and of good quality, solid to the center; plant very vigorous and hardy; extremely productive. Medium season.

RIDGEWAY. A splendid, large, regularly shaped berry, of good color and firm texture. In flavor, it is equal to any grown, and is a remarkably good market berry. The plant is very vigorous and hardy, remaining in bloom a long time; it is therefore one of the best pollenizers for pistillate varieties.

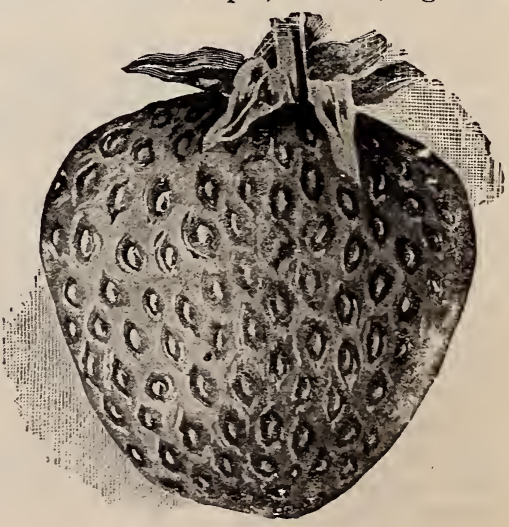

Ruby Strawberry. (See page 29.) 
STRAWBERRIES, continued.

RUBY. A berry of western origin, which has attracted much attention wherever grown. It is wonderfully prolific, each plant bearing enormous quantities of large, dark red, firm and exquisitely flavored berries, which are a dark red clear through.

Saunders. An excellent berry, that is very popular with those who have grown it. Of a beautiful shade of red; rich in flavor and firm of texture. Best in light soil.

Sharpless. Another old standard, which requires a good, rich soil to bring it to perfection. Berries very large, irregular in shape, light crimson, firm, and of a very good quality; a heavy bearer and a good shipper.

Splendid. Really a "splendid" berrry in all that the term implies. Has faculty of standing extreme heat and drought as well. A strong grower and a great producer of large berries if over-production of plants be checked.

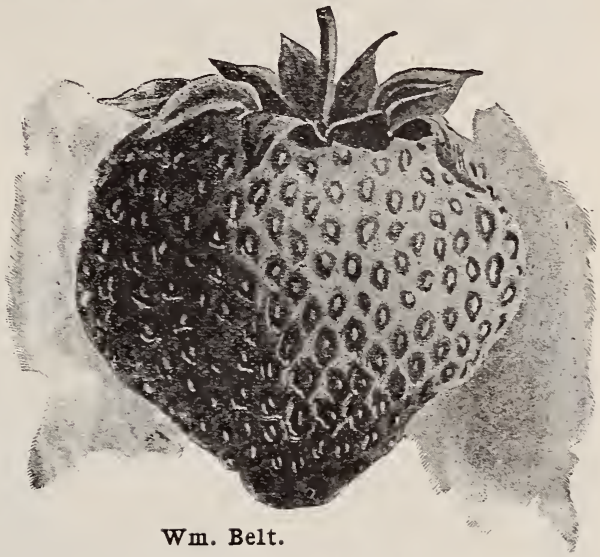

STAR. One peculiarity of this berry is its great drought-resisting qualities, it always maturing a complete crop when other varieties have been complete failures. It is second early in ripening, and one of the most profitable berries that can be grown, always bringing "fancy prices." Of large size and beautiful color, and rery firm and sweet.

Sunrise. (P). An improvement on Crescent, but an equally heavy bearer. Very early and good for market; of a rich, deep, dark red, and good flavor and texture.

Tennessee Prolific. A seedling of Sharpless and Crescent, showing characteristics of both. Large and handsome. It is noted for its beautiful, healthy foliage and finely colored fruit. It is one of the very best berries we know.

Timbrell. A comparatively new variety, which has made a wonderful name for itself. The berries are extra large and fine, and carry well; plants are very strong, healthy and prolific.

Tubbs. A Maryland berry from Anne Arundel county. Very early and productive; high in quality and flavor, and a good all-round berry.

Van Deman. A good, bright red berry of great productiveness; the berries are of good uniform size and great beauty, very sweet, and of good texture.

WARFIELD. (P.) A splendid, dark, glossy red berry of medium size and very firm. It is a splendid shipper and always commands the highest price in market. One of the best varieties for canning.

Wm. Belt. A new variety which is meeting with a great deal of favor wherever it is introduced. A very high colored berry, ripening evenly to the tip; extra large in size and pointed in shape; a splendid shipper. It attracts attention in the markets beyond any other variety. Plant is an exceedingly strong and heavy bearer, and the fruit, in addition to its immense size, is of excellent quality and fine flavor.

Woolverton. A Canadian seedling, which is very large and attractive. Plants are strong and healthy, continuing long in fruit. Berries very large.

\section{Currants.}

Plant in good, deep soil, in a cool location, and do not be chary of manure. Set in rows 5 feet apart, and 4 feet apart in the rows. Cultivate like raspberries, and mulch heavily, for good crops. Keep well thinned out.

First-class, 2 years old, 12 cts. each, $\$ 1$ per 10, \$6 per 100, $\$ 50$ per 1,000, except where otherwise noted.

Cherry. Very large and red, with a long bunch of great beauty and excellent quality. A splendid fruit for garden planting. 
CURRANTS, continued.

Fay's Prolific. A larger Currant than the former, and much more productive. Bunches 5 to 6 inches in length; plants strong, healthy and hardy. I5 cts. each, $\$ 1.25$ per Io, $\$$ Io per IOo, $\$ 60$ per I,000.

North Star. A comparatively new variety, with a bunch growing to 4 inches in length. Fruit is very rich and sweet, and it is a good market berry; particularly good for jelly. $20 \mathrm{cts}$. each, $\$$ I.50 per Io, $\$$ I2 per IOO, $\$ S 0$ per I,000.

Red Dutch. This is the old and familiar garden variety, which still retains its popularity. Of medium size, in large bunches. Profitable for market.

Versailles. Much like Cherry, and almost as large as Fay's. Large, bright crimson; bushes hardy and prolific.

White Grape. A splendid white variety-in fact the only white Currant of any value. Of splendid quality, large and very productive.

WILDER. A strong, upright grower and very productive of large, long bunches of immense berries, which are bright red, and of splendid flavor; the fruit has the valuable quality of keeping in good condition a long time after it is ripe; this makes it a splendid market variety.

\section{Raspberries.}

Prepare the soil much in the same way as for strawberries. Set the plants in rows 7 feet apart and 3 feet apart in the rows, pressing the soil firmly around them. Give them the same cultivation as you would corn, working the ground perfectly flat. Manure plentifully the first year, and pinch the ends out of the canes when about a foot high. In the second year let them grow to $\mathrm{I} / 2$ feet. After the fruit is gathered, cut out and burn all old wood and young canes but the best three. This will destroy all insects and insure a better growth.

CUMBERLAND. This new claimant for honors in the Raspberry market has fully sustained the great reputation it made so soon after its introduction. It is, without doubt, the finest black Raspberry ever grown, far exceeding in every respect that old standard, Gregg, which has been a favorite so long. It is the most profitable and desirable market variety, being termed "Business Blackcap" by the introducers, it selling for Io cents a quart when other varieties brought but 5 to 7 cents. It is of immense size, some specimens measuring a full inch across. Extremely hardy; it has withstood a temperature of 16 degrees below zero without injury. It is wonderfully productive, of the finest quality, unusual firmness, and ripens about the middle of the season. Extra fine plants, $\$$ I per doz., $\$ 5$ per Ioo, $\$ 35$ per I, 000 .

Miller Red. This new red Raspberry has attracted widespread attention ever since its introduction, and is a very great favorite in the part of Delaware where it originated. The fruit is fully as large as Cuthbert in its palmy days, but perfectly

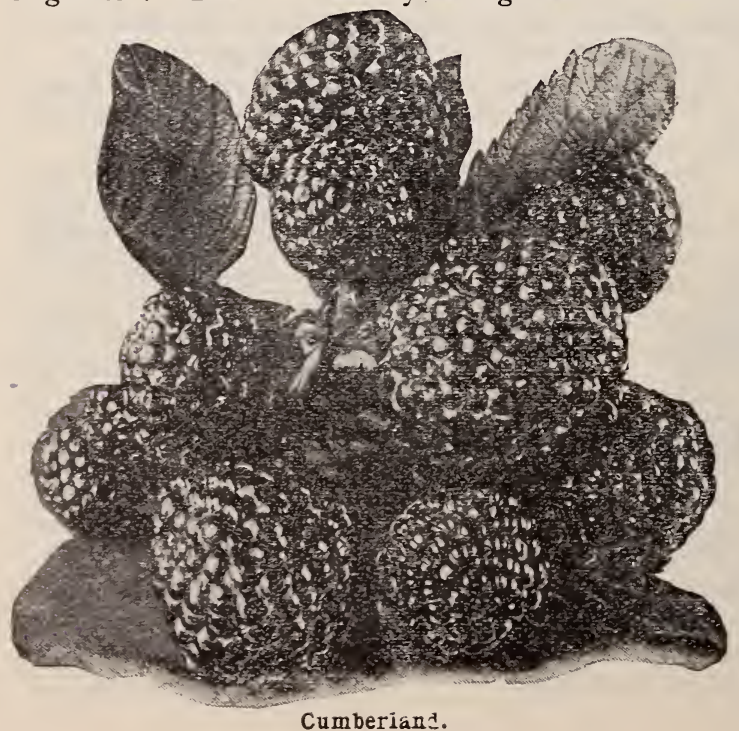
round. The color is bright red, retaining its brightness after picking longer than any other variety. The core is very small. As a shipping berry it excels anything in the market, as it does not crumble under any circumstances. Its flavor is peculiarly fruity and rich. It is one of the earliest, the first picking being done about the second week in June, and continuing until the first of August. It is particularly valuable on account of its profuse crops, and seems to adapt itself equally well to all sorts of soils-light sandy, gravelly, or heavy clay. We unhesitatingly recommend it as the best red Raspberry in the market today. We quote extra strong plants, 50 cts. per doz., $\$ 1.20$ per IOO, $\$ 8$ per I,, 00 . 


\section{Blackberries.}

Set the rows 7 feet apart, with plants 3 feet apart in the row. Four or 5 feet apart is sufficient for garden culture. Culture like raspberries, leaving but three canes to the hill.

Iceberg. The new white Blackberry, the paradox of the fruit world. This wonderful berry is the origination of the far-famed Luther Burbank, whose remarkable success in the production of valuable $\mathrm{n}$ e w plants has given him the title of the "Wizard of Horticulture." The well-known Lawton, which is, when ripened, unsurpassed in quality, and very generally known as a most profitable market variety, was a great-grandparent of the Iceberg. The fruit is not only white, but so transparent that the seeds, which are unusually small, can be seen in the ripe berries. The clusters are larger than those of Lawton individual berries as 1 a rge: earlier, sweeter, more tender and melting throughout, though as firm as Lawton when ripe.

Lucretia (Dewberry). Large, very early, handsome, and of exceptionally good flavor. Extremely hardy and prolific; of a trailing habit. $25 \mathrm{cts}$ per doz., $\$ 1$ per Ioo, $\$ 7$ per I,000.

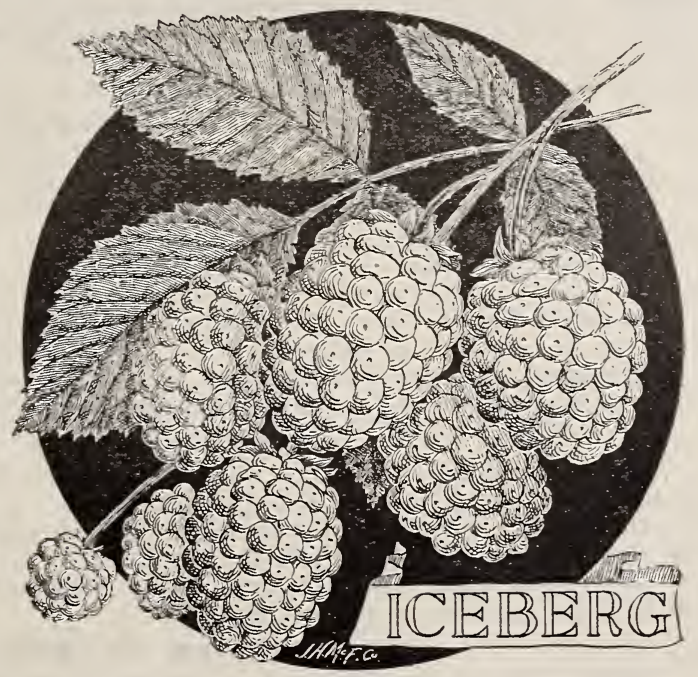

Early Harvest. The earliest of all Blackberries, and very sweet. It is extremely hardy and a wonderful bearer. $25 \mathrm{cts}$. perdoz., \$I per Ioo, $\$ 7$ per I,000.

Eldorado. Very large, with small seeds ; ripens after Wilson. Particularly fine in quality; very productive. Io cts. each, $75 \mathrm{cts}$. per doz., $\$ 4$ per 100, $\$ 30$ per I, 000 .

Erie. A large, early berry of high quality. Plant fruitful, hardy and strong. 50 cts. per doz., \$1.50 per IOo, \$IO per I,000.

Wilson Early. One of the standard early sorts. Always finds a ready sale in market. 25 cts. per doz., $\$ 1.25$ per I00, $\$ 8$ per 1,000 .

\section{Gooseberries.}

The culture given to currants is all that is necessary for Gooseberries. Avoid mildew, the great enemy of the Gooseberry, by planting in partial shade, and keep the plants well mulched.

Our plants are all first-class, 2-year-olds.

Downing. A very popular berry of large size ; pale green in color, and of excellent quality. The bunch is strong, hearty and prolific. I5 cts. each, $\$$ I per Io, $\$ 8$ per I00, $\$ 60$ per I,000.

Houghton. The old standard; pale red and very sweet. A steady and regula, bearer; very productive and free from mildew. I5 cts. each, $\$ 1$ per Io, $\$ 8$ per roor $\$ 60$ per I, ooo.

Red Jacket. One of the largest of the Gooseberries. Its absolute freedom from mildew makes it one of the most valuable sorts. The berry is of a dark red, without spines, and is deserving of a place either for home or market cultivation. $25 \mathrm{cts}$. each, $\$ 2$ per Io, \$16 per Ioo, \$140 per I,000. 


\section{Grapes.}

The Grape is the most satisfactory of all fruits to raise, as it can be put to so many different uses. It can be confined to a stake, bound to a trellis, trained over an arbor, or to cover a large building, and under all conditions will yield its delicious fruit. No fruit will give better returns for close attention and kind care, and good returns can be had from soils which are unfit for any other crop. The side of a hill freely exposed to the sun and air is an ideal place for Grape culture, whether the soil be sandy, clayey or loamy. Careful pruning is necessary for good crops, and should be done when the vine is entirely dormant. Thinning out the young bunches will more than pay the cost by the increased size and quality of the fruit allowed to mature. All our vines are strong, vigorous 2-year-old stock, and guaranteed to give perfect satisfaction.

\section{BLACK GRA PES.}

Champion, or Talman. A large Grape, clear of rot, and very prolific; early. Io cts. each, 75 cts. per doz., $\$ 3$ per Ioo, $\$ 20$ per $\mathrm{I}, 000$.

Concord. The old standard. Very productive; medium in season. 10 cts., each, 50 cts. per doz. $\$ 2$ per IOO, $\$$ I 5 per I,000.

Hartford Prolific. A very hardy Grape; large, compact bunch; berries large, sweet and juicy ; very early. Io cts. each, $75 \mathrm{cts}$. per doz., $\$ 4$ per Ioo, $\$ 35$ per I,000.

Moore's Early. Very large ; a fine Grape for home or market; early. Io cts. each, 75 cts. per doz., $\$ 4$ per Ioo.

Worden. An improved Concord, and a little earlier. One of the best blacks. Io cts. each, 75 cts. per doz., $\$ 4$ per Ioo, $\$ 35$ per $\mathrm{I}, 000$.

\section{RED GRAPES.}

Agawam (Rogers' No. 15). Very large ; skin thick; sweet and early. Io cts. each, \$I per doz., \$4 per Ioo, \$25 per I,000.

Delaware. Small, but exceedingly fine. A leading early market Grape. I5 cts. each, $\$$ I per doz., $\$ 5$ per Ioo, $\$ 40$ per I, 000.

Wyoming Red. Double the size of Delaware; vine strong; early. Io cts. each, 75 cts. per doz., $\$ 4$ per Ioo, $\$ 35$ per I,000.

\section{WHXTE GRAPFS.}

Lady. One of the best white Grapes. Extra early; very hardy and prolific. Io cts. each, $75 \mathrm{cts}$. per doz., $\$ 3$ per Ioo.

Martha. Very reliable. Good for wine or market; medium in season. Io cts. each, 60 cts. per doz., $\$ 3$ per Ioo.

Niagara. One of the best known whites. A splendid table Grape; medium. Io cts. each, $75 \mathrm{cts}$. per doz., $\$ 4$ per Ioo, $\$ 30$ per I,000.

Pocklington. Largest and most showy white; a standard of its class. Very hardy and prolific; medium. Io cts. each, 75 cts. per doz., $\$ 4$ per 100, $\$ 35$ per I,000. We can furnish any other variety, if desired. Prices upon application.

\section{DECIDUOUS TREES.}

Our stock of shade trees are all good, strong and hardy, and we guarantee satisfaction if proper attention is given to planting. We quote:

Norway Maple. One of the most satisfactory trees in existence; broad-leaved, ornamental and distinct; very handsome, either as a single specimen or planted in a group. $50 \mathrm{cts}$. each, $\$ 5$ per doz.

Sugar Maple. One of the best known of the Maples; of noble form, and valuable for its wood and sugar. $40 \mathrm{cts}$. each, $\$ 3.60$ per doz.

Carolina or Cottonwood Poplar. A splendid tree where quick growing is a desideratum. Beautiful in shape and luxuriant in foliage. Particularly valuable for city streets. $30 \mathrm{cts}$. each, $\$ 2$ per doz.

\section{DECIDUOUS HEDGE PLANTS.}

OSAGE ORANGE and CALIFORNIA PRIVET. Perhaps the cheapest, quickest and most satisfactory plant for hedges is the California Privet. In two or three years, with fair treatment, it makes a close, compact and beautiful hedge. It is especially adapted for lawns. Plant deep, 8 to Io inches apart. Prices as follows :

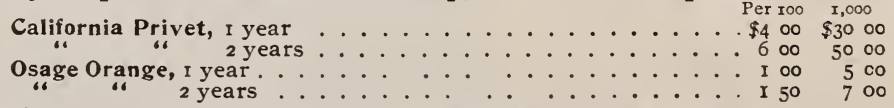

List and prices of other Deciduous Trees and Evergreens will be gladly furnished upon application. 


\section{ORDER SHEET.}

\section{M. PETERS' SONS,}

\section{MESLEY, MARYLAND.}

Forward to

Name of Person

Name of Post Office

Name of Express Office

Name of Freight Station

Name of County.

Name of State
(Ladies please sign Miss or Mrs.)

Amount enclosed :

P. O. Order . .\$

Draft . . . . \$

Exp.Money Order. $\$$

Casb . . . . \$

Total . . . \$

roo ITo order filled for less than $\$ I$.

SUBSTITUTION. - It frequently occurs that special varieties ordered have been in great demand and the stock has been exhausted. In such cases we will not substitute unless you ask us to, but your money will be returned. If you want us to send the next best, we will. Shall we substitute or not? Yes or No.

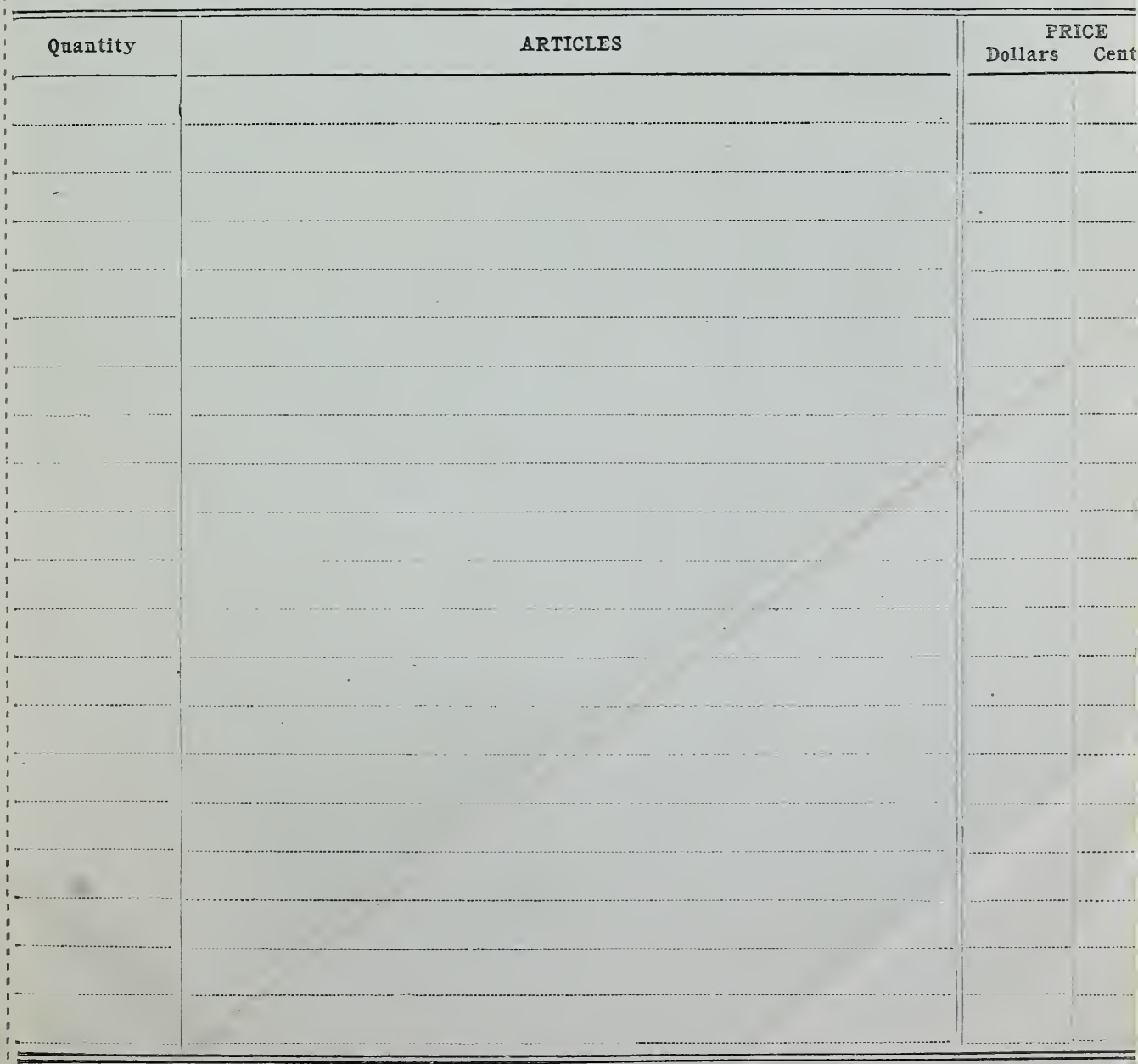


ORDER SHEET, continued.

zuantity $\quad$ ARTICLES

please give names and addresses of a few friends who are interested in fruit-groving, and we will be glad to add enough extra stock to your order to pay for your kindness.

NAME




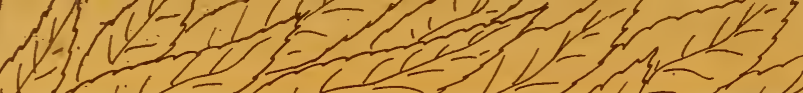

It- 1
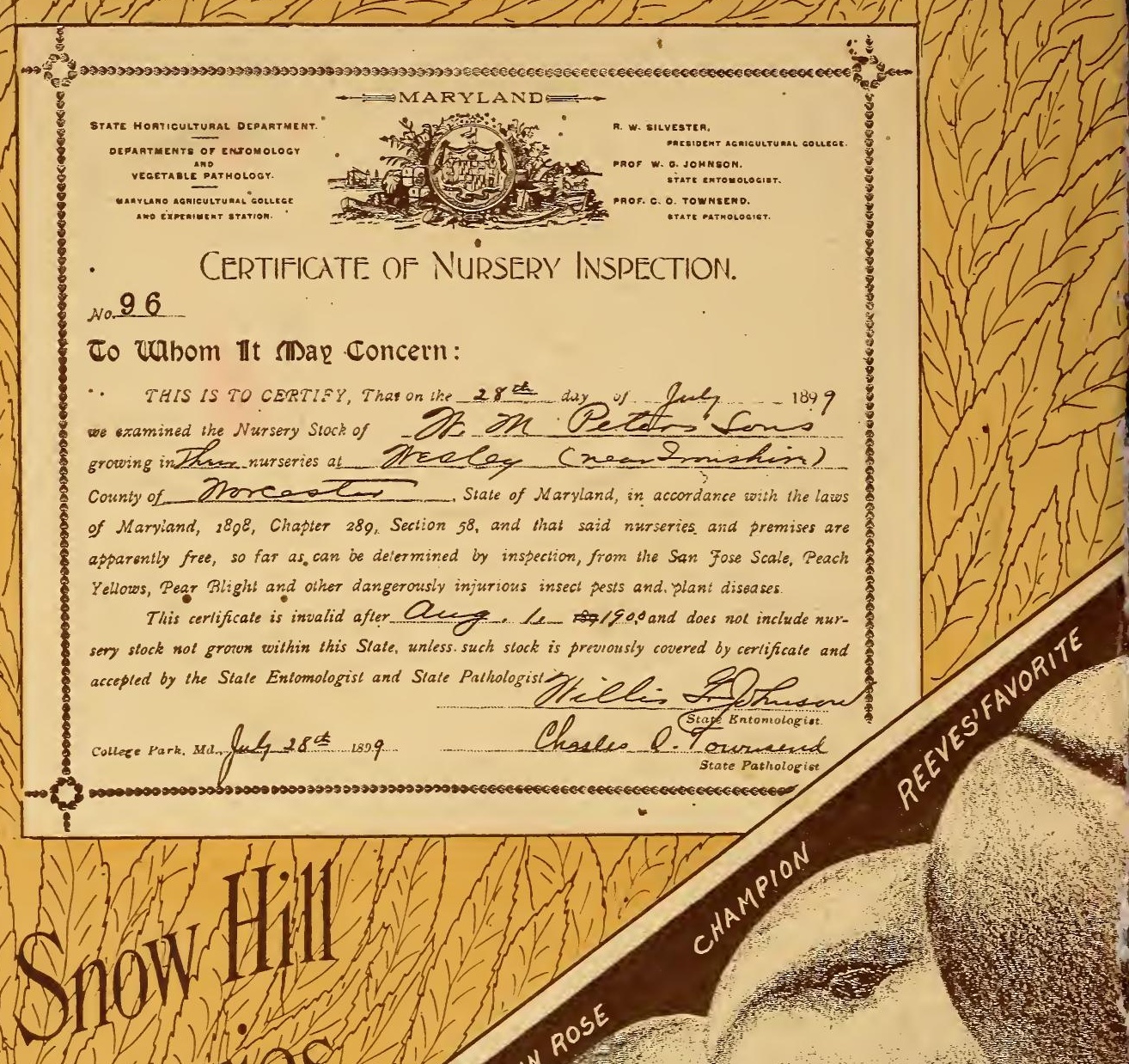

Nivseses

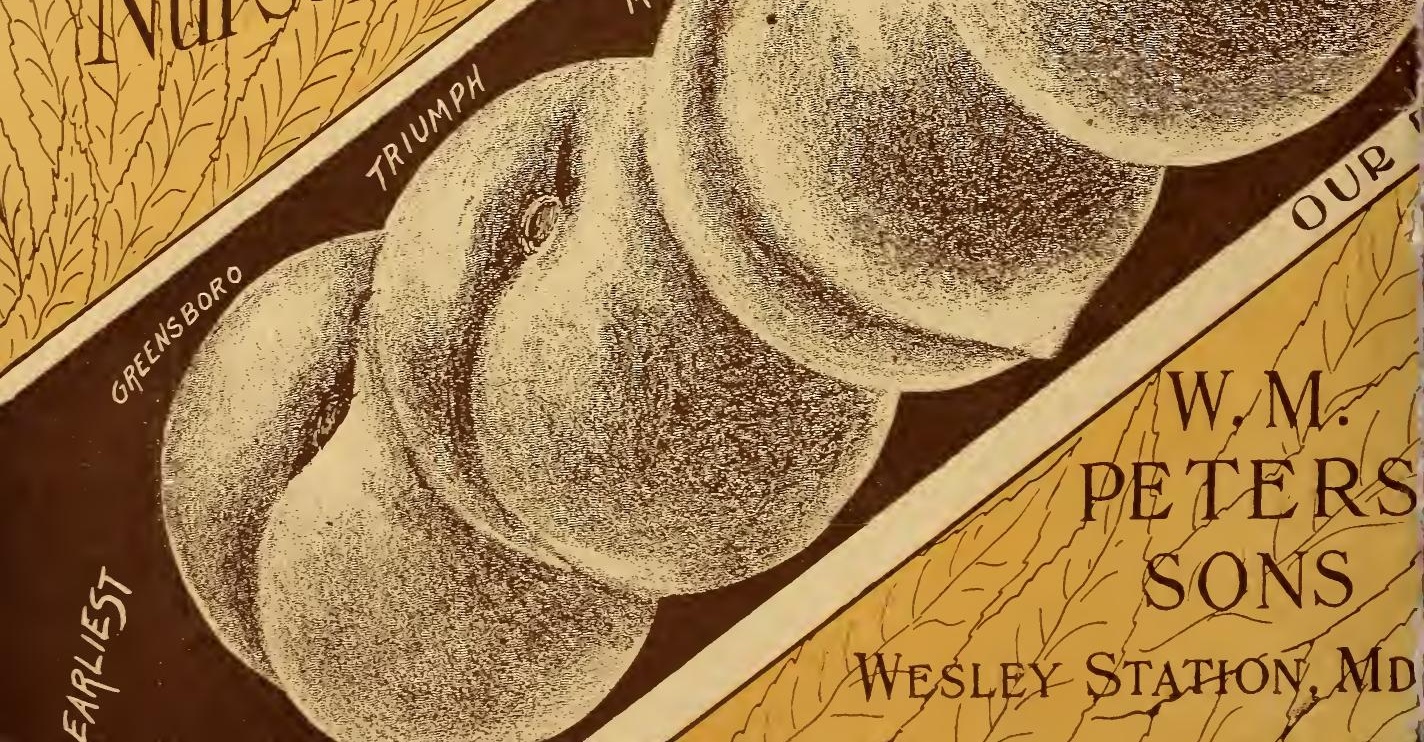

